\title{
The Development, Preservation and Loss of Differential Case Marking in Inner Asia Minor Greek
}

\author{
Petros Karatsareas \\ Lecturer in English Language and Linguistics, School of Humanities, \\ University of Westminster, London, United Kingdom \\ P.Karatsareas@westminster.ac.uk
}

\begin{abstract}
In Cappadocian and Pharasiot, the two main members of the inner Asia Minor Greek dialect group, the head nouns of NPs found in certain syntactic positions are marked with the accusative if the relevant NPs are definite and with the nominative if the NPs are indefinite. This differential case marking (DCM) pattern contrasts with all other Modern Greek dialects, in which the accusative is uniformly used in the relevant syntactic positions. After revisiting recent proposals regarding the synchronic status of DCM in Cappadocian and Pharasiot, I show how the two dialects developed this 'unGreek' feature in the model of Turkish, which marks the head nouns of direct object NPs with an accusative suffix only if they take a specific reading leaving non-specific direct object NPs unmarked. I subsequently trace the diachronic trajectory of this contact-induced innovation within the two dialectal systems, seeking to explain why DCM was gradually lost in Cappadocian but preserved in Pharasiot.
\end{abstract}

\section{Keywords}

differential case marking - differential object marking - language contact - Asia Minor Greek - Cappadocian -Pharasiot - Turkish

\section{Introduction}

Inner Asia Minor Greek (henceforth iAMGr) is a Modern Greek (ModGr) dialect group that includes Cappadocian, Pharasiot, and Silliot. All three dialects 
were spoken in the Cappadocian plateau of inner Asia Minor (today's central Turkey) by Greek Orthodox communities until 1924, when Greece and Turkey exchanged populations in accordance with the 1923 Treaty of Lausanne, which forced iAMGr speakers to relocate in Greece. Long before the exchange, the Greek-speaking people of Asia Minor had come into political and cultural contact with Turkish-speaking peoples, dating back to the invasion of the Seljuq Turks in parts of the peninsula even before the defeat of the Byzantine troops at Manzikert in 1071. The subsequent separation of the Greek populations of Asia Minor from the administrative centre of Constantinople; the consecutive dehellenisation of much of Asia Minor; the subsequent disintegration and fall of the late Byzantine Empire in 1453; and, the ultimate domination of the whole of Anatolia by Turkic groups, most notably the Seljuqs and the Ottomans, resulted in Asia Minor Greek developing for many centuries in linguistic isolation from the Greek-speaking contingent of the west, on the one hand, and in intense language contact with surrounding Turkish, on the other.

Owing to these sociohistorical conditions (see Dawkins, 1916; Janse, 2002; Karatsareas, 2011, 2013; Manolessou, 2019 for details), iAM Gr presents the linguist with features tracing their origin to earlier stages in the history of the Greek language but also with many grammatical innovations that are found nowhere else in the Greek world. In many of these innovations, the effects of language contact with Turkish are particularly evident. Suffice it to mention here the introduction into the Greek phonemic inventory of Turkish phonemes such as $/ \propto /, / \mathrm{y} /, / \mathrm{w} /$ and $/ \mathrm{q} /$, and the merger of the interdental fricatives $/ \theta /$ and $/ \delta /$ with either the alveolar stops $/ \mathrm{t} /$ and $/ \mathrm{d} /$, the alveolar fricatives $\mid \mathrm{x} /$ and $/ \mathrm{y} /$, the sibilant $/ \mathrm{z} /$, or the rhotic /r/ (Dawkins, 1916: 74-80; Janse, 2009: 40); the borrowing of Turkish inflectional material and the replication of the structure of Turkish inflected forms (Janse, 2001, 2004, 2009; Karatsareas, 2011, 2016a); the use of the interrogative particle $m i(<$ Turkish $m I$ ) to mark yes/no and alternative questions (Bağrıç̧ı, 2013; Janse, 2009); and, the generalised shift from head-initial to head-final order in various syntactic domains, most notably in the DP and the AdpP (Janse, 2009; Karatsareas, 2011, 2013, 2016; Karatsareas and Georgakopoulos, 2016; Lekakou and Karatsareas, 2016).

In this article, I examine the diachrony of one such contact-induced innovation attested in the two main iAMGr dialects, Cappadocian and Pharasiot: the development of differential case marking (henceforth DCM). The term is employed here to refer to the alternation in the case used to mark the head nouns, and possibly also other constituents, of NPs found in the following syntactic positions: direct object, indirect object, light verb complement, object predicative, adpositional complement, and temporal adjunct. The alternation involves 
two inflectionally expressed cases, the nominative and the accusative, in such a way that the former marks the head nouns of indefinite NPs and the latter those of definite NPs. ${ }^{1}$ ModGr does not show this type of alternation. Rather, accusative marking is uniformly found in all the aforementioned syntactic positions with the exception of a considerable number of dialects-including the standard language - in which indirect objects are marked by the genitive. In Turkish, however, a case alternation pattern is found in the encoding of direct objects whereby the accusative suffix - $(y) I$ only marks head nouns whose referents take a specific reading whereas nouns denoting non-specific referents remain zero-marked.

Previous works have convincingly concluded that the development of DCM in iAMGr was contact-induced and brought about by the influence of Turkish. Against this backdrop, the aim of this article is twofold: (a) to test the proposals that have been formulated in the literature regarding the synchronic status of Cappadocian and Pharasiot DCM in the light of recent advances in the typological-crosslinguistic study of differential argument marking in general (in the sense of Seržant and Witzlack-Makarevich, 2018); and, (b) to trace its diachronic trajectory within the two dialectal systems taking into account recent work on the history of the iAMGr inflectional system that provided the essential morphological material for the implementation of the differential case alternation. Specifically, my synchronic analysis addresses the issue of the referential property that determines DCM in Cappadocian and Pharasiot, challenging Spyropoulos and Tiliopoulou's (2006) proposal that DCM in the two dialects is determined by specificity and not by definiteness as originally argued by Dawkins (1916) and later supported by Janse (2004). My diachronic analysis examines the fate of DCM in the two dialects, seeking to explain why DCM was lost in Cappadocian varieties but retained in Pharasiot. In short, I argue that, in Cappadocian, the morphological material that was employed for the expression of DCM was affected and ultimately lost as a result of an unrelated morphological change, which Pharasiot—crucially—did not undergo.

The article is structured as follows: in Section 2, I give a typological overview of the phenomenon of differential argument marking, briefly presenting the different ways in which the phenomenon is manifested crosslinguistically. Section 3 contrasts the two contact languages, ModGr and Turkish, in terms of their (non-)differential case marking systems. Section 4 examines and analyses DCM in Cappadocian and Pharasiot in terms of its synchrony (4.1), emergence (4.2), and preservation and loss (4.3). Section 5 concludes the article.

1 A few rare instances of DCM are also attested in Silliot; see the discussion in 4.2. 
Seržant and Witzlack-Makarevich (2018) use the broad term differential argument marking to refer to the crosslinguistically widespread phenomenon whereby "an argument of a predicate bearing the same generalized semantic role (or macrorole) may be coded in different ways, depending on factors other than the argument role itself and/or the clausal properties of the predicate". The most well-known and well-studied example of such a situation is the differential marking of direct objects, which occurs in a wide range of languages and which led to Bossong's (1982) coining of the term Differential Object Marking (henceforth DOM) (Aissen, 2003; Bossong, 1985, 1991, 1998; Comrie, 1989; Croft, 1988, 2003; Dalrymple and Nikolaeva, 2011; von Heusinger and Kornfilt, 2005; Iemmolo, 2011, 2013; Klein and de Swart, 2011; Lyons, 1999; Malchukov, 2008; Moravcsik, 1978; de Swart, 2007).

There are two types of DOM systems: symmetric and asymmetric. In symmetric systems, a subset of direct objects bears one type of overt marking while another subset of direct objects bears some other type of overt marking. Compare the two markers on the direct object in the Finnish example in (1). In the affirmative clause in (1a), the direct object is marked by the accusative; in the negative clause in $(1 b$,$) it is marked by the partitive case. { }^{2}$

2 Finnish, Spanish and Turkish data are given in the standard orthography of each respective language. Hebrew and Greek data are given in broad phonetic transcription. The only exceptions for Greek are (a) the use of the acute accent to indicate stress; and, (b) the use of $<i>$ to represent a glide that is an allophone of $/ \mathrm{i} /$. When preceding a tautosyllabic vowel, the glide surfaces as [j] after voiced obstruents and as [ç] after voiceless obstruents. In the case of consonants that can be palatalised $(\mathrm{k} \longrightarrow \mathrm{c}, \mathrm{g} \longrightarrow \mathrm{j}, \mathrm{x} \longrightarrow \mathrm{c}, \mathrm{\gamma} \longrightarrow \mathrm{j}, \mathrm{l} \longrightarrow \kappa, \mathrm{n} \longrightarrow \mathrm{n}$ ), the glide causes palatalisation and is subsequently absorbed by the resultant palatalised consonant. The following abbreviations are used throughout the article including in the glosses of the examples: 1: first, 2: second, 3: third, ABL: ablative, ACC: accusative, АСт: active, Сом: comitative, СомP: complementiser, СOP: copula, DAT: dative, DCM: differential case marking, DEF: definite, DIM: diminutive, DIST: distal, DOM: differential object marking, DSM: differential subject marking, EXCL: exclamation, F: feminine, FN: factive nominal, FUT: future, GEN: genitive, IAMGR: inner Asia Minor Greek, IC: inflectional class, IMPFV: imperfective, IMPV: imperative, INDF: indefinite, INT: interior, LOC: locative, M: masculine, ModGr: Modern Greek, N: neuter, NEG: negative, NOM: nominative, NP: noun phrase, OBJ: object, PART: partitive, PL: plural, PN: proper name, PNP: perfective non-past, POSs: possessive, PROX: proximal, PRXT: proximate, PRS: present, PST: past, PTCP: participle, QUOT: quotative, SG: singular, sıM: similative. 
(1) Finnish
a. $s \ddot{-}-i-n$
kaku-n
eat-PST-1SG
cake-ACC
'I ate the cake.'

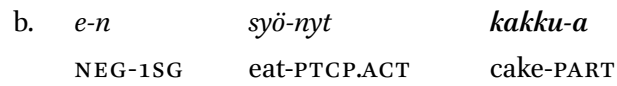

'I did not eat the cake.'

In asymmetric systems, only a subset of direct objects bears overt marking while the remaining direct objects appear zero-marked. This is the case in Modern Hebrew and Spanish. In Hebrew, only definite direct object NPs are overtly marked by the prepositional element et (2a); indefinite NPs do not bear any overt marking (2b) (Danon, 2001; Givón, 1978: 305-306; Glinert, 1989).

(2) Modern Hebrew
a. axalti et ha-uga
eat.PST.1SG ACC DEF-cake(F).SG
'I ate the cake.'
b. axalti
eat.PST.1SG
$\varnothing \quad$ uga
'I ate (a) cake.'

Similarly, in Spanish, direct object NPs are overtly marked by the preposition $a$ only if they take a specific reading and their referents are human (3a,b); if their referents have a non-specific reading or are not human, they bear no overt marking (3c, d) (von Heusinger, 2008 and references therein).

(3) Spanish (Comrie, 1989: 134)
a. busco
al
empleado
look_for.PST.1SG
DAT.DEF.M.SG
$\operatorname{clerk}(\mathbf{M}) . \mathrm{sG}$

'I am looking for the clerk.'

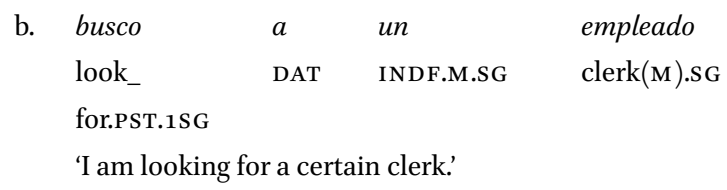



c. busco
$\varnothing \quad$ un
empleado
look_for.PST.1SG
INDF.M.SG
$\operatorname{clerk}(\mathrm{M}) . \mathrm{sG}$
'I am looking for a clerk.'
d. busco
$\varnothing \quad e l$
carro
look_for.PST.1SG
DEF.M.SG
$\operatorname{car}(\mathbf{M}) . \mathrm{SG}$
'I am looking for the car.'

Drawing mainly on cases such as those presented by Hebrew and Spanish, early studies identified animacy and definiteness as the two referential properties that typically condition DOM phenomena crosslinguistically, often representing them by means of hierarchies (Aissen, 2003; Bossong, 1998; Comrie, 1989; Croft, 1988, 2003). The two versions of the Animacy Hierarchy in (4) rank the referents of NPs on the basis of whether they are animate and human (or human-like).

Animacy Hierarchy (adapted from Dahl, 2000: 99)
a. animate
b. human $>$ inanimate

The Definiteness Hierarchy in (5) ranks NPs with respect to the values their referents have for (in)definiteness and (non-)specificity.

(5) Definiteness Hierarchy (von Heusinger, 2008: 5; see also Aissen, 2003: 437)

$\begin{aligned} & \text { personal } \\ & \text { pronoun }\end{aligned}>\begin{aligned} & \text { proper } \\ & \text { name }\end{aligned}>\begin{aligned} & \text { definite } \\ & \text { NP }\end{aligned}>\begin{aligned} & \text { indefinite } \\ & \text { specific NP }\end{aligned}>\begin{aligned} & \text { indefinite non- } \\ & \text { specific NP }\end{aligned}>\begin{aligned} & \text { non-argumental } \\ & \text { NP }\end{aligned}$

Definiteness is assumed by Lyons (1999: 274-281) to be a grammatical category expressing the discourse pragmatic notions of identifiability and inclusiveness. Definite NPs are considered identifiable in the sense that their referents are familiar to both speaker and hearer because they have already been established in discourse or on the basis of general knowledge of the world. Definite NPs are considered inclusive in so far as they refer to the totality of objects or mass in the context which satisfy the description (Lyons, 1999: 11). ${ }^{3}$ The referents of indefinite NPs, on the other hand, are non-identifiable, in that they are

3 Other scholars define definiteness in terms of other notions such as familiarity, uniqueness, and reference; see Lyons (1999). 
not known and familiar to the hearer because they have not been mentioned before, and non-inclusive, in that they never refer to the totality of objects or mass in the context which satisfy the description but rather to a single member of the total set of objects or to a certain amount of the total mass. The former semantic characteristic of indefinite NPs underpins their major function, which is to introduce new discourse referents into the discourse. Two types of indefinite NPs are usually distinguished in the literature: specific and nonspecific. In pre-theoretical terms, in the case of specific indefinite NPs, the speaker has a referent in mind, which they want to introduce into the discourse and is unknown to the hearer. Non-specific indefinite NPs do not refer to any particular object or referent that the speaker has in mind but denote any entity that can fulfil the semantic requirements of the relevant description.

Starting with Karttunen (1968), a multitude of scholars have attempted to define and formally describe the notion of specificity in terms of notions such as the referential versus existential distinction, partitivity, presuppositionality, the weak versus strong quantifiers distinction, topicality, topic continuity, referential persistence, and noteworthiness; see von Heusinger (2011a) for an overview and references. Von Heusinger (2011a) argued that there is a core notion underlying all proposed interpertations of specificty, namely, referential anchoring. According to this proposal, "the referent of a specific indefinite is functionally dependent on some discourse participant or on another expression in the sentence" (von Heusinger 2011a: 1054). He goes on to identify the following seven types of specificity:

1. referential specificity, whereby specific indefinites yield readings that allow existential entailment whereas non-specific indefinites do not;

2. scopal specificity, which concerns the ability of certain indefinites to escape scope islands;

3. epistemic specificity, which relates to the contrast between speaker's knowledge and speaker's ignorance (or indifference) about the referent of the indefinite;

4. $\quad$ specificity as partitivity and presuppositionality;

5. specificity as topicality, where topical elements are understood as specific expressions;

6. specificity as noteworthiness; and,

7. specificity as discourse prominence.

Focusing on type (vii), von Heusinger (2011a) defines discourse prominence in terms of three aspects: noteworthiness, referential persistence, and topic continuity. Discourse referents are considered noteworthy if they have significant, unexpected or interesting properties. Referential persistence is the property of 
being frequently picked up in the subsequent discourse, whereas topic continuity is the property of becoming or remaining the topic of the discourse. Indefinite NPs that show high degrees of noteworthiness, referential persistence, and topic continuity are considered specific. For applications of this approach to specificity, see Chiriacescu and von Heusinger 2010, von Heusinger 2002, $2011 \mathrm{~b}$ as well as references therein.

More recently, a number of works have started to draw attention to DOM systems that are not conditioned by referential properties of the linguistic expressions found in the direct object position but, rather, by semantic properties of the verb such as affectedness and boundedness, polarity, and quantification (Dalrymple and Nikolaeva, 2011; Hoop and Malchukov, 2008; Iemmolo, 2011, 2013). In that connection, Iemmolo's (2013) typological study found that there is a correlation between the property or properties that condition DOM and the (a)symmetry of the Dом system in a given language. He has specifically argued, based on a sample of 159 languages, that asymmetric alternations are conditioned by referential properties of the referent encoded by the direct object NP while symmetric alternations are conditioned by verbal semantics. The Hebrew, Spanish and Finnish examples adduced in this section confirm the proposed correlations.

\section{The Contact Languages}

I have previously argued (Karatsareas 2011, 2013, 2016b) that, present-day ModGr and present-day Turkish, especially their standard forms, are not the "appropriate reference varieties" (Poplack and Levey, 2010: 395) to compare when attempting to establish the causes of change observed in iAM $\mathrm{r}$ r, whether they be internally-motivated or contact-induced. Previous research has shown that iAMGr followed a different evolutionary trajectory than ModGr dialects spoken in other parts of the wider eastern Mediterranean basin at least since the Late Medieval period (see, among others, Dawkins, 1916; Janse, 2002; Karatsareas, 2011, 2013; Manolessou, 2019). One would therefore ideally want to compare the iAMGr data with data drawn from varieties of Greek and Turkish that are closer to AMGr from a historical and/or a geographical point of view. However, the almost complete dearth of texts written in inner Asia Minor in dialectal Greek or Turkish in the period before the $19^{\text {th }}$ century renders this type of comparison impossible. Present-day ModGr and present-day Turkish are, for that reason, chosen as the next best available points of reference thanks to the wealth of data and linguistic analyses that are easily accessible for them. As far as the development of DCM is concerned, suffice it to mention that the type of 
case alternation that is observed in iAMGr is not known to have been a feature of Medieval Greek.

\subsection{ModGr: A Non-Differential Language}

In ModGr, no case alternations of the type presented in Section 2 are found in any of the syntactic positions in which we find DCM in iAMGr. The accusative uniformly marks direct object NPs (6); indirect object NPs, though only in some dialects including the iAM Gr dialects (7) (for details, see Manolessou and Beis, 2006); benefactives, again only in some dialects including iAMGr (8);4 light verb complements (9); object predicatives (10); full phrasal adpositional complements (11); and, temporal adjuncts of the type shown in (12). Observe that accusative marking is found with both definite and indefinite NPs, and with both animate and inanimate referents. ${ }^{5}$

ModGr, direct object

a. $\sin ^{(n)} \operatorname{dis} a$

meet.PST.1SG

fílo

friend(M).SG.ACC sto

LOC.DEF.M.SG.ACC $m u$

1SG.GEN ðrómo

street(M).SG.ACC

to

DEF.M.SG.ACC to

DEF.M.SG.ACC manóli PN(N).SG.ACC

'I came across my friend Manolis on the street.'

b. $\operatorname{siná}^{(n)}$ disa

meet.PST.1SG

fílo

friend(M).SG.ACC sto

LOC.DEF.M.SG.ACC

$m u$,

1SG.GEN ðrómo

street(M).SG.ACC

to

DEF.M.SG.ACC énan

INDF.M.SG.ACC

manóli

PN(N).SG.ACC

'I came across a friend of mine on the street, Manolis.'

4 In other ModGr dialects including the standard language, indirect objects and benefactives are marked by the genitive. In all dialects, indirect objects and benefactives can also be introduced by the preposition se followed by an accusative-marked NP.

5 (In)definiteness in ModGr is marked by means of the definite and the indefinite articles as well as by a zero article. The definite article is used with a wide range of NPs of varying semantic types: from simple definite and generic NPs to possessive and proper noun NPs (Lyons, 1999: 337; Napoli, 2009). Indefinite NPs are marked by the indefinite article or by the zero article. Definite NPs generally have a specific reading except for generic NPs, which are nevertheless stil marked by the definite article. Indefinite NPs marked as such by the indefinite article can have both a specific and a non-specific reading whereas bare indefinite NPs can be interpreted as either non-specific or generic (Clairis and Babiniotis, 2004: 21-43; Holton et al., 1997: 276-285; Schroeder, 2006: 582-584, Theofanopoulou-Kontou et al., 1998: 11-29; Tzartzanos, 1989: 170-18o). 
(7) ModGr, indirect object (some dialects, including iAMGr)
a. ipa
ton
ksáðerfo
$m u$
tin
tell.PST.1SG
DEF.M.SG.ACC
$\operatorname{cousin}(\mathrm{M}) . \mathrm{SG} . \mathrm{ACC}$
1SG.GEN
DEF.F.SG.ACC
istoría
story(F).SG.ACC

'I told the story to my cousin.'
b. ípa énan ksáðerfo mu tin
tell.PST.1SG DEF.M.SG.ACC cousin(M).SG.ACC 1SG.GEN DEF.F.SG.ACC
Istoría
story(F).SG.ACC
'I told the story to a cousin of mine.'

(8) ModGr, benefactive (some dialects, including iAMGr)

$\begin{array}{llll}\text { ayórase } & \text { me } & \text { cimá } & n a \quad \text { ftçákso } \\ \text { buy.IMPV.2SG } & \text { 1SG.ACC } & \text { minced_meat(M).SG.ACC } & \text { COMP make.PNP.1SG } \\ \text { to } & j o & s u & \text { ceftédes } \\ \text { DEF.M.SG.ACC } & \text { son(M).SG.ACC } & \text { 2SG.GEN } & \text { meatball(M).PL.ACC }\end{array}$

'Buy some minced meat for me so that I make meatballs for your son.'

(9) ModGr, light verb complement
a. $o$
ðímarxos
éryale
ton
DEF.M.SG.NOM
mayor(M).SG.NOM
take_out.PST.3SG
DEF.M.SG.ACC
lójo
stin
platía
$\operatorname{speech}(\mathrm{M})$. .SG.ACC
LOC.DEF.SG.ACC
square(F).sG.ACC

'The mayor gave the speech at the square.'

b. $o$

$\begin{array}{llll}o & \text { Jímarxos } & \text { éryale } & \text { (énan) } \\ \text { DEF.M.SG.NOM } & \text { mayor(M).SG.NOM } & \text { take_out.PST.3SG } & \text { INDF.M.SG.ACC } \\ \text { lóyo } & \text { stin } & \text { platía } & \end{array}$

speech(M).SG.ACC LOC.DEF.SG.ACC square(F).SG.ACC

'The mayor gave a speech at the square.'

(10) ModGr, object predicative

$\begin{array}{llll}o & \text { proistámenos } & \text { ton } & \text { órise } \\ \text { DEF.M.SG.NOM } & \text { supervisor(M).SG.NOM } & \text { 3SG.M.ACC } & \text { appoint.PST.3SG } \\ \text { nixtofilaka } & & \\ \text { nightwatchman(M).SG.ACC } & & \\ \text { 'The supervisor appointed him nightwatchman.' } & \end{array}$


(11) ModGr, adpositional complement pira
take.PST.1SG bread(N).sG.ACC
'I bought bread from the bakery.'

apó ton

ABL DEF.M.SG.ACC

fúrno

bakery(M).SG.ACC

b. píra

$$
\text { psomí }
$$

take.PST.1SG bread(N).sG.ACC

\section{apó énan}

fúrno

'I bought bread from a bakery.'

(12) ModGr, temporal adjunct

a. ton

DEF.M.SG.ACC

$$
\text { ceró }
$$
polá

time(M).SG.ACC

ecíno

Jen ixame

DIST.M.SG.ACC NEG have.PST.1PL

many.N.PL.ACC money(N).PL.ACC

'In those days, we did not have much money.'

b. énan

INDF.M.SG.ACC

ceró $i$

time(M).sG.ACC

mána

ABL INDF.M.SG.ACC

bakery(M).SG.ACC

DEF.F.SG.NOM

mother(F).SG.NOM

$\begin{array}{lll}p u \quad m^{\prime} & \text { éstelne } \\ \text { COMP } \quad \text { 1SG.ACC } & \text { send.PST.IMPFV.3SG } \\ m u & & \text { sxolío } \\ \text { 1SG.GEN } & \text { school(N).SG.ACC }\end{array}$

'Once upon a time, when my mother used to send me to school...'

ModGr is, therefore, non-differential in its case marking system. It is, nevertheless, classified by Bossong (1991:151) as exhibiting an accusative-neutral split in view of the fact that only nouns that belong to non-neuter-i.e., masculine and feminine-inflectional classes (henceforth ICs) have a distinct form for the accusative case. Neuter nouns do not distinguish morphologically between the nominative and accusative, which are always expressed by a single syncretic form. While Bossong sees this as a kind of differential split, he does not consider it to be on a par with Dom patterns of the Hebrew or Spanish type. In these languages, DOM is synchronically active as it is based on semantic and pragmatic properties of the referents of direct object NPs, which may vary and therefore allow for the observed alternations in object marking. In contrast, the ModGr accusative-neutral split does not allow for any degree of variability. It is defined by inflectional class, which is a strictly intralinguistic feature and has little or no bearing on meaning.

In effect, however, due to a number of phonological and morphological developments that affected nominal inflection in earlier stages in the history of the language, the accusative-neutral split applies only to nouns belonging to Ralli's (2000, 2005) Inflectional Class 1 (IC1) and to the singular of IC2 nouns, 
which are the only ones in which the accusative is expressed by a form distinct from that of the nominative. ${ }^{6}$ Compare, in that connection, the ACC.SG forms of the head nouns shown in (6)-(12) with their NOM.SG forms shown in (13). Observe that the nominative versus accusative distinction is morphologically marked by the presence versus absence of final -s.

(13) ModGr

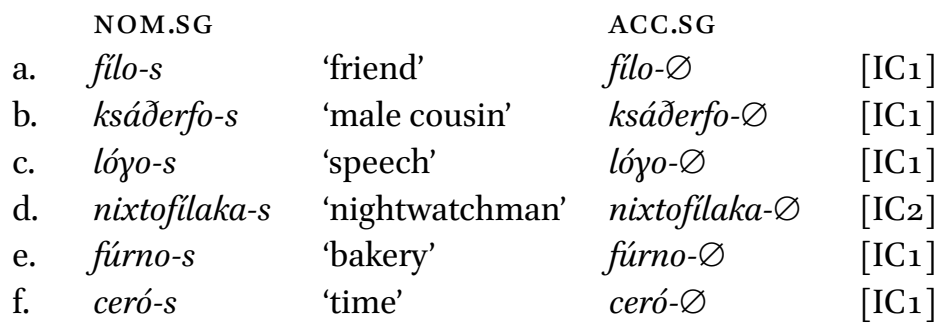

In all other ICs, nominative and accusative are always syncretic. As one reviewer correctly notes, however, this state of affairs holds only for those ModGr dialects in which word-final $-n$, a historical marker of the accusative singular, has been lost. This includes the standard language but also the inner Asia Minor Greek dialects that I deal with in this article. In dialects that retain wordfinal /n/ - for example, Dodecanesian, Cypriot, or Pontic - a morphological distinction between nominative and accusative singular is also found in ICs 3 and 4; compare Cypriot Greek jenéka 'woman(F).SG.NOM' with jenékan 'woman(F).SG.ACC' (IC3), and póli 'city(F).SG.NOM' with pólin 'city(F).SG.NOM'.

\subsection{Turkish: A Differential Language}

Unlike ModGr, Turkish is a differential language in which a case alternation pattern is found in the marking of direct objects. In Turkish, only the head nouns of direct object NPs whose referents are specific receive overt marking by means of the accusative suffix - $(y) I$. The head nouns of non-specific NPs, on

6 According to Ralli's analysis, ModGr nouns are categorised into eight ICs, which are defined on the basis of (a) the set of suffixes that are employed to mark the six case/number combinations that compose the ModGr nominal paradigm, and (b) allomorphic variation in nominal stems. Stems are lexically specified for gender and IC whereas suffixes are specified for number, case and IC. Given that ModGr distinguishes between three gender values (masculine, feminine, neuter) and has eight nominal ICs, it becomes clear that the groupings of nouns into gender classes and ICs do not overlap. Rather, nouns are assigned to particular gender classes on the basis of their IC specification so that nouns that belong to IC1 are either masculine of feminine, nouns that belong to IC2 are masculine, nouns that belong to ICs 3 and 4 are feminine, and nouns that belong to ICs $5^{-8}$ are neuter. 
the contrary, bear no overt marking (Göksel and Kerslake, 2005: 201-203; von Heusinger and Kornfilt, 2005: 4-5; Kornfilt, 1997).

This textbook case of DOM is exemplified in (14). In (14a), the head noun anahtar 'key' is marked by - $(y) I$ and appears without the indefinite article bir. As a result, the NP receives a definite and, therefore, specific reading. The same holds in (14b), in which the direct object NP additionally contains the demonstrative bu 'this'. In (14c), $-(y) I$ co-occurs with bir, the combination of the two yielding an indefinite specific reading. (14d) has an indefinite non-specific reading as evidenced by the use of bir and lack of $-(y) I$. One reviewer notes that, very often in cases such as this one, the referent of the indefinite NP is known to the speaker but is judged to be pragmatically irrelevant to the conversation. Finally, in (14e), zero marking on the noun combined with the lack of bir has been argued to show that anahtar is not an argument in the transitive relation but has a reading similar to that of incorporating constructions (Aydemir, 2004; Erguvanll, 1984).

(14) Turkish
a. Yasemin- $\varnothing$ anahtar-ı kaybet-ti. PN key-ACC lose-PST
'Yasemin lost the key'
b. Yasemin- $\varnothing$ bu anahtar-ı kaybet-ti. PN PROX key-ACC lose-PST
'Yasemin lost this key.'
c. Yasemin- $\varnothing$ bir anahtar-ı kaybet-ti. PN INDF key-ACC lose-PST

'Yasemin lost a certain key'
d. Yasemin- $\varnothing$ bir anahtar- $\varnothing$ kaybet-ti. PN INDF key lose-PST

'Yasemin lost a key'
e. Yasemin- $\varnothing$ anahtar- $\varnothing$ kaybet-ti. PN key lose-PST

'Yasemin lost keys.'

In terms of the Definiteness Hierarchy (5), the cut-off point for overt direct object marking in Turkish therefore lies between indefinite specific NPs and indefinite non-specific NPs, with all NPs whose specificity values fall to the left of the latter being marked by $-(y) I$ (Fig. 1). 

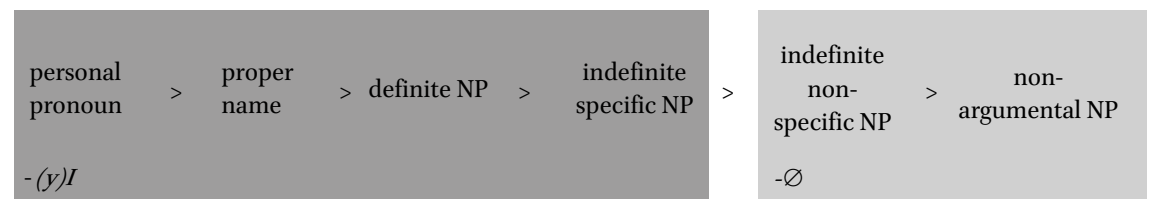

FIGURE 1 DOM in Turkish.

Crucially, the zero-marked form of the direct object noun in ( $14 \mathrm{~d}-\mathrm{e})$ is the one used, inter alia, for the subject of main clauses as in (15) (Göksel and Kerslake, 2005: 173-175; Kornfilt, 1997: 212-214).

(15) Turkish

$\begin{array}{lll}\text { Anahtar- } \varnothing & \text { paspas-ın } & \text { alt-ın- } d a \\ \text { key } & \text { doormat-GEN } & \text { bottom-POSS.3SG-LOC }\end{array}$

'The key is under the doormat.'

\section{The iAMGr DCM System}

The data used for the analysis presented in this section have been drawn from a Cappadocian and Pharasiot corpus consisting of the published and unpublished texts shown in Table 1:

TABLE 1 The texts of the Cappadocian and Pharasiot corpus.

Source

\section{A. Cappadocian}

Dawkins (1916: 304-464)

Kesisoglou (1951: 136-161)

Fosteris (1952: 161-177)

Kostakis (1959: 46-61, 64, 82, 88-90, 94, Mistí

$146,154,176,196,198-200)$

Fosteris and Kesisoglou (1960: 98-127)

Mavrochalyvidis and Kesisoglou (1960:

186-221)

Tsitsopoulos (1962: 18-24, 26, 31-36, 38-40, 44, 48-82, 84-93, 95-99, 101, 103-106)

\section{Varieties}

Delmesó, Ferték, Araván,

Ghúrzono, Ulaghátsh, Mistí, Axó,

Malakopí, Phloïtá, Sílata, Potámia

Ulaghátsh

Araván

Araván

Axó

Phloïtá 
TABLE 1 The texts of the Cappadocian and Pharasiot corpus. (cont.)

\begin{tabular}{ll}
\hline Source & Varieties \\
\hline Kostakis $(1962: 1-11,12-19,21,23,28$, & Phloïtá \\
$29-30,83-102,112-141,149-157$, & \\
$159-160,164-166,172-174,176-187$, & \\
$192-203,216-238,272,274,276-280$, & \\
$284-285,289)$ & \\
B. Pharasiot & \\
Dawkins $(1916: 464-579)$ & Phárasa, Tshukúri, Kíska, \\
& Afshar-köi \\
\hline
\end{tabular}

\subsection{Synchrony}

Cappadocian and Pharasiot stand out among the ModGr and, in fact, all Greek varieties - ancient and modern - in having developed into differential languages in which a case marking alternation is found in the following syntactic positions: direct object, indirect object, light verb complement, object predicative, adpositional complement, and temporal adjuncts (Anastasiadis, 1976: 89-102; Andriotis, 1948: 47; Bağrıaçık, 2018: 59-65 ; Dawkins, 1916: 94, 164-165, 1950: 357-358; Janse, 2004; Spyropoulos, 2016; Spyropoulos and Kakarikos, 2009, 2011; Spyropoulos and Tiliopoulou, 2006). The iAMGr pattern is conditioned by definiteness and formally implemented by means of the morphological distinction between nominative and accusative so that nominative marking is found with indefinite NPs and accusative marking is found with definite NPs. Examine the examples in (16)-(20). Observe that DCM applies to both animate and inanimate nouns.

(16) Pharasiot, direct object (Dawkins, 1916: 540)

$\begin{array}{llll}\text { adé } & \text { to } & \text { ffókro } & \text { dóseté } \\ \text { PROX } & \text { DEF.N.SG.ACC } & \text { boy.DIM(N).SG.ACC } & \text { give.IMPV.2PL OBJ } \\ \text { to } & \text { mutsúko } & \text { to } & \text { xazná. } \\ \text { DEF.M.SG.ACC } & \text { little.N.SG.ACC } & \text { DEF.M.SG.ACC } & \text { treasure(M).SG.ACC } \\ \text { le } & d i & \text { to } & \text { ffókro } \\ \text { say.PRS.3SG } & \text { COMP } & \text { DEF.N.SG.NOM } & \text { boy.DIM(N).SG.NOM } \\ \text { go } & \text { xaznás } & \text { dzo } & \text { irévo } \\ \text { 1SG.NOM } & \text { treasure(M).SG.NOM } & \text { NEG } & \text { look_for.PRS.1SG }\end{array}$

"'Give this boy, the little fellow, the treasure." The little boy says, "I do not ask for treasure." 
(17) Phlö̈tá Cappadocian, indirect object (Tsitsopoulos, 1962: 58)

$\begin{array}{llllll}\text { etó } & \text { to } & \text { á } \text { ropo } & m i & \text { to } & \text { lalít } \\ \text { PROX.SG } & \text { DEF.SG.ACC } & \text { man.SG.ACC } & \text { NEG } & \text { 3SG.ACC } & \text { talk.PRS.2PL }\end{array}$

'Do not talk to this man.'

(18) Araván Cappadocian, light verb complement (Fosteris, 1952: 170)

saránda méres ce saránda níxtes épkan

forty day.PL.ACC and forty night.PL.ACC do.PST.3PL

yámos

wedding.sG.NOM

'They had a wedding that lasted for forty days and forty nights.'

(19) Phloïtá Cappadocian, object predicative (Kostakis, 1962: 228)

$\begin{array}{llll}t^{\prime} & \text { álo } & \text { to } & \text { mejálo } \\ \text { DEF.SG.ACC } & \text { other.SG.ACC } & \text { DEF.SG.ACC } & \text { old.sG.ACC } \\ \text { ékanan } & \text { to } & \text { vasíós } & \\ \text { do.PST.3PL } & \text { 3SG.ACC } & \text { king.SG.NOM } & \end{array}$

'They made the other one, the older one, a king.'

(20) Delmesó Cappadocian, adpositional complement (Dawkins, 1916: 322)
a. $s e$ sálsan $s^{\prime} \quad$ éna
2SG.ACC send.PST.3PL LOC INDF
batáx tópos
slippery.sG place(M).SG.NOM
'They sent you to a slippery place.'
b. so

$\begin{array}{ll}\text { filan } & \text { son } \\ \text { such.SG } & \text { LOC.DEF.M.SG.ACC } \\ \text { éna } & \text { korítf } \\ \text { INDF } & \text { girl(N).SG.NOM }\end{array}$
tópo
LOC.DEF.N.SG.ACC
en
INDF $\operatorname{girl}(\mathrm{N}) . S G . N O M$
COP.PRS.3
'In such and such a place there is a girl.'
place(M).sG.ACC

According to a recent proposal by Spyropoulos and Tiliopoulou (2006), DCM in Cappadocian is not conditioned by definiteness but, rather, by specificity as in Turkish. In their analysis, the nominative marks the head nouns of non-specific NPs, which can only be indefinite, and the accusative marks those of specific NPs, which can be either definite or indefinite. Two predictions follow from this analysis regarding the case marking of indefinite NPs: first, that they should be marked by the nominative if their referents are interpreted as 
non-specific; second; that they should be marked by the accusative if their referents are specific. Neither, however, is borne out by the iAMGr data.

Looking first at nominative-marked indefinite NPs, we find that they can very well have a specific reading. Consider the excerpts in (21) and (22). In (21), the indefinite NP an ipnos 'a dream' introduces into the discourse the dream that the little boy had. That the boy has a particular dream in mind and that the NP therefore denotes a particular referent can be adduced on the basis of referential persistence as the dream is picked up a number of times and by different linguistic expressions in the subsequent discourse. It is, specifically, picked up twice by other indefinite NPs of the same form, four times by definite NPs of the form ton ípno, and five times by the object marker da/ta. In the three paragraphs that follow and which are not provided here for the sake of space, the same referent is picked up four times by other indefinite NPs of the same form, three times by definite NPs of the form ton ipno, and nine times by the object marker da/ta.

(21) Pharasiot (Dawkins, 1916:536)

\begin{tabular}{|c|c|c|c|}
\hline sikó»i & $d z e$ & $b a$ & sikóきi. \\
\hline rise.PST.3SG & And & again & rise.PST.3SG \\
\hline$s$ & an & próto & zamáni \\
\hline LOC & INDF & first.N.SG.ACC & time(N).sG.ACC \\
\hline ítun & $a$ & néka & $d z$ \\
\hline COP.PST.3PL & INDF & woman(F).SG.NOM & and \\
\hline an & ándras. & íxan & $a$ \\
\hline INDF & $\operatorname{man}(\mathrm{M}) \cdot$.SG.NOM & have.PST.3PL & INDF \\
\hline ijós. & to & ffókro & ¿ðеn \\
\hline $\operatorname{son}(\mathrm{M}) \cdot \mathrm{SG} \cdot \mathrm{ACC}$ & DEF.N.SG.NOM & boy.DIM(M).SG.NOM & see.PST.3SG \\
\hline an & ípnos. & ipen & $d i$ \\
\hline INDF & dream(M).SG.NOM & say.PST.3SG & СОМР \\
\hline jo & ¿ða & $a n$ & ípnos. \\
\hline 1SG.NOM & see.PST.1SG & INDF & dream(M).sG.NOM \\
\hline ípen & $i$ & $m a$ & $t u$ \\
\hline Say.PST.3SG & DEF.F.SG.NOM & mother(F).SG.NOM & 3SG.N.GEN \\
\hline pe & $m e$ & $d a$. & dzo \\
\hline say.IMPV.2SG & 1SG.ACC & овJ & NEG \\
\hline lézo & $d a$. & $g a$ & katakóltsen \\
\hline Say.PRS.1SG & овј & well & chase.PST.3SG \\
\hline$d a$. & sotípos & dzo & les \\
\hline овЈ & Why & NEG & say.PRS.2SG \\
\hline ton & ípno? & éfije & to \\
\hline
\end{tabular}




\begin{tabular}{|c|c|c|c|}
\hline $\begin{array}{l}\text { DEF.M.SG.ACC } \\
\text { ffókro. }\end{array}$ & $\begin{array}{l}\text { dream }(\mathrm{M}) . \mathrm{SG} \cdot \mathrm{ACC} \\
\text { vrádine. }\end{array}$ & leave.PST.3SG & $\begin{array}{l}\text { DEF.N.SG.NOM } \\
\text { irte }\end{array}$ \\
\hline boy.DIM(M).SG.NOM & become_evening.PST. & $3 \mathrm{SG}$ & come.PST.3SG \\
\hline$t u$ & ffók:u & $o$ & dadás. \\
\hline DEF.N.SG.GEN & boy.DIM(M).SG.GEN & DEF.M.SG.NOM & father(M).SG.NOM \\
\hline$a$ & néka & $p u$ & píje \\
\hline EXCL & woman(F).SG.VOC & where & go.PST.3SG \\
\hline to & ffókro? & $z$ & ine \\
\hline DEF.N.SG.NOM & boy.DIM(M).SG.NOM & HORT & COP.PRS.3SG \\
\hline$t u$ & деvoú & to & \\
\hline DEF.M.SG.GEN & $\operatorname{devil}(\mathrm{M})$. SG.GEN & DEF.N.SG.NOM & \\
\hline ffókro. & ఓðе & an & ípnos. \\
\hline boy.DIM(M).SG.NOM & see.PST.3SG & INDF & dream(M).SG.NOM \\
\hline ípa & $d i$ & pe & me \\
\hline say.PST.1SG & COMP & say.IM PV.2SG & 1SG.ACC \\
\hline ton & ípno. & dzúpe & me \\
\hline DEF.M.SG.ACC & dream(M).SG.ACC & NEG.say.PST.3SG & 1SG.ACC \\
\hline$d a$. & $d z$ & oyó & páli \\
\hline овЈ & And & 1SG.NOM & again \\
\hline katakóltsa & $t a$. & ípen & $d i$ \\
\hline chase.PST.1SG & овJ & say.PST.3SG & COMP \\
\hline$o$ & tatás & pe & $t a$ \\
\hline DEF.M.SG.NOM & father(M).SG.NOM & say.IMPV.2SG & овJ \\
\hline$n a$ & nárti & to & \\
\hline COMP & come.PNP.3SG & DEF.N.SG.NOM & \\
\hline fJókro & $n a$ & $m e$ & ipi \\
\hline boy.DIM(M).SG.NOM & СОМР & 1SG.ACC & say.PNP.3SG \\
\hline ton & ípno. & írte & to \\
\hline DEF.M.SG.ACC & dream(M).sG.ACC & come.PST.3SG & DEF.N.SG.NOM \\
\hline ffókro. & ípen & $d i$ & pe \\
\hline boy.DIM(M).SG.NOM & say.PST.3SG & СОМР & say.IMPV.2SG \\
\hline me & $t a$ & $t u$ & ఓðes \\
\hline 1SG.ACC & овJ & REL & see.PST.2SG \\
\hline ton & ípno. & ipen & $d i$ \\
\hline DEF.M.SG.ACC & dream(M).SG.ACC & say.PST.3SG & СOMP \\
\hline to & ffókro. & $o$ & tatá \\
\hline DEF.N.SG.NOM & boy.DIM(M).SG.NOM & EXCL & father(M).SG.VOC \\
\hline$d z o$ & léo & se & $t a$. \\
\hline NEG & say.PRS.1SG & 2SG.ACC & овJ \\
\hline$k a$ & katakóltsen & $d a$ & $o$ \\
\hline
\end{tabular}




$\begin{array}{llll}\text { well } & \text { chase.PST.3SG } & \text { OBJ } & \text { DEF.M.SG.NOM } \\ \text { tatás } & \text { to } & \text { ffókro. } & \\ \text { father(M).SG.NOM } & \text { DEF.N.SG.ACC } & \text { boy.DIM(M).SG.ACC } & \end{array}$

'He rose up and again he rose up. In the old days, there were a woman and a man. They had a son. The little boy saw a dream. He said, "I saw a dream." His mother said, "Tell it to me." "I will not tell it." She drove him right away. "Why do you not tell your dream?" The little boy ran away. It became evening. The little boy's father came. "Wife, where has the little boy gone?" "May the little boy go to the devil. He saw a dream. I said 'Tell me the dream'. He did not tell me it. And I then drove him out." The father said, "Tell the little boy to come, to tell me the dream." The little boy came. He said, "Father, I will not tell it to you." His father drove the little boy right out.'

In (22), the indefinite NP éna devréfis introduces into the discourse the dervish that the hero of the story met at the edge of the village. In this case, that éna devréfis takes a specific reading can be adduced on the basis of referential persistence and topic continuity. The same referent is picked up again in the immediately subsequent sentence by the definite NP to devré and further down the text twice by the definite NP devréis. Crucially, in the sentence that begins with ce devréis, the dervish becomes the topic of the discourse as it is the subject of the verbs ber 'takes', lex 'says', and ber 'takes'. In the paragraph that follows and which is again not provided for the sake of space, the dervish remains the topic of the discourse as it is the subject of no fewer than eight verbs (lex 'says', anix 'opens', vyal 'takes out', Jixni 'shows', fusá 'blows' (twice), éðiksen 'showed', psófsen 'died'). It that paragraph, the dervish is overtly picked up twice by the definite NP devréis, once by the definite NP do devréf, and twice by the third person singular pronoun $d o$.

(22) Phloïtá Cappadocian (Dawkins, 1916:414)

$\begin{array}{llll}\text { abefí } & \text { pen } & s & \text { éna } \\ \text { ABL.DIST } & \text { go.PRS.3SG } & \text { LOC } & \text { INDF } \\ \text { álo } & \text { tópos. } & \text { pen } & s \\ \text { other.SG } & \text { place.SG.NOM } & \text { go.PRS.3SG } & \text { LOC } \\ \text { éna } & \text { xorjó. } & \text { abéso } & \text { ðé } \\ \text { INDF } & \text { village.SG.ACC } & \text { INT } & \text { NEG } \\ \text { men } & c e & \text { filágni } & \text { xorjú } \\ \text { enter.PRS.3SG } & \text { and } & \text { wait.PRS.3SG } & \text { village.SG.GEN } \\ \text { nákra. } & \text { istera } & \vartheta \text { orí } & \text { éna } \\ \text { edge.SG.ACC } & \text { Afterwards } & \text { see.PRS.3SG } & \text { INDF } \\ \text { devréfis. } & \text { ce } & \text { to } & \text { devréf } \\ \text { dervish.SG.NOM } & \text { And } & \text { DEF.SG.ACC } & \text { dervish.SG.ACC }\end{array}$




\begin{tabular}{|c|c|c|c|}
\hline léi & to & ébar & kondá \\
\hline say.PRS.3SG & 3SG.ACC & take.IMPV.2SG & PRXT \\
\hline$s$ & as & jenó & to \\
\hline 2SG.GEN & HORT & become.PNP.1SG & DEF.SG.NOM \\
\hline редi & $s$. & $c e$ & ðén \\
\hline boy.SG.NOM & 2SG.GEN & and & NEG \\
\hline to & ber. & $c e$ & lex \\
\hline 3SG.ACC & take.PRS.3SG & and & say.PRS.3SG \\
\hline ðará & sabaxátça. & xayłés & $a z$ \\
\hline now & ornament.PL.NOM & which & $\mathrm{ABL}$ \\
\hline maftú & $t$ & $t a$ & peðjá \\
\hline RECIP & 3SG.GEN & DEF.PL.ACC & boy.PL.ACC \\
\hline xair & ðén & ७orí? & $c$ \\
\hline pleasure.sG.ACC & NEG & see.PRS.3SG & and \\
\hline ejóna & $a b$ & esé & $t i$ \\
\hline 1SG.NOM & $\mathrm{ABL}$ & 2SG.ACC & what \\
\hline xaír & $n a$ & ¡jo? & $c$ \\
\hline pleasure.sG.ACC & FUT & see.PNP.1SG & and \\
\hline ecí & to & реді & lex \\
\hline DIST & DEF.SG.NOM & boy.SG.NOM & say.PRS.3SG \\
\hline ðé & se & tróło & ja \\
\hline NEG & 2SG.ACC & eat.PRS.1SG & EXCL \\
\hline kondá & $\mathrm{s}$ & $n a$ & cimi७ó \\
\hline PRXT & 2SG.GEN & FUT & sleep.PNP.1SG \\
\hline$n a$ & sikoঐó. & devréis & níete \\
\hline FUT & rise.PNP.1SG & dervish.SG.NOM & become.PRs.3sG \\
\hline karjá & $t$ & $c e$ & to \\
\hline heart.sG.NOM & 3SG.GEN & and & 3SG.ACC \\
\hline ber & kondá & $t$. & \\
\hline take.PRS.3SG & PRXT & 3SG.GEN & \\
\hline
\end{tabular}

'He goes from there to another place. He goes to a village. He does not go into it, and he waits at the edge of the village. Afterwards he sees a dervish. And he says to the dervish, "Take me with you. Let me become your boy." And the dervish does not accept him and says, "This is a fine thing now! Who does not have pleasure in his own children? And I, what pleasure shall I have in you?" And the boy there says, "I will not eat you surely. Let me sleep and rise with you." The dervish lets him have his way and takes him with him.'

Nominative-marked indefinite NPs can also have non-specific readings as in (23), in which the non-referential qavurmás can only be non-specific in 
its function as an object predicative. The same holds for the light verb complement yámos in the Cappadocian example in (18), which is also nominativemarked.

\begin{tabular}{|c|c|c|c|}
\hline \multicolumn{4}{|c|}{ Pharasiot (Dawkins, 1916: 476) } \\
\hline sákseté & $t a$ & \multicolumn{2}{|l|}{ pídzeté } \\
\hline kill.IMPV.2PL & овЈ & \multicolumn{2}{|l|}{ make.IMPV.2PL } \\
\hline ta & qavurmás & faíseté & ta. \\
\hline овЈ & dried_meat(M).sG.NOM & feed.IMPV.2PL & овЈ \\
\hline éfsaksan & to & jáði & píkan \\
\hline kill.PST.3PL & DEF.N.SG.ACC & $\operatorname{cow}(\mathrm{N}) \cdot \mathrm{SG} \cdot \mathrm{ACC}$ & make.PST.3PL \\
\hline$t a$ & qavurmás & fáisan & to \\
\hline $\mathrm{OBJ}$ & dried_meat(M).sG.NOM & feed.Pst.3PL & DEF.M.SG.ACC \\
\hline \multicolumn{4}{|l|}{ qavurmá } \\
\hline \multicolumn{4}{|c|}{ dried_meat(M).sG.ACC } \\
\hline
\end{tabular}

Turning now to accusative-marked indefinite NPs, it must be noted that they are very rarely attested in the Cappadocian texts and not at all found in the Pharasiot texts. In the few cases in which such NPs are found in Cappadocian, they should be either interepreted as an instance of the competition between the Greek accusative-neutral split, as it was exemplified with ModGr in 3.1, and the novel DCM system or should be attributed to influence from non-differential ModGr varieties. Still, the examination of the few attested cases shows that such NPs can take both a specific and a non-specific reading. Compare, for example, én'a đelfó in (24) with éna kánona in (25). The former clearly has a specific reading. It is difficult to imagine a scenario whereby the speaker uses an indefinite NP meaning 'a brother' without referring to the particular brother that they have. The latter, on the other hand, has a non-specific reading. In this text, a woman gives birth to a camel instead of a human being, and the woman's relatives pay a visit to the local bishop to ask for advice. The bishop has not heard anything like this before, he opens up his books to look for an appropriate ecclesiastical rule for cases such as the one at hand but finds no such rule in the books because such a rule does not exist. It is therefore safe to assume that éna kánona is a non-specific indefinite. ${ }^{7}$

7 Non-specific accusative-marked direct object NPs are also found in Turkish under specific morphosyntactic conditions; see von Heusinger and Kornfilt (2005). 
(24) Potámia Cappadocian (Dawkins, 1916:454)

éxo én' aðelfó c' ecíno ef

have.PRS.1SG INDF brother.SG.ACC and DIST.SG.NOM have.PRS.3SG

ta

3PL.ACC

'I have a brother and he has them.'

(25) Araván Cappadocian (Fosteris and Kesisoglou, 1960: 98)

inikse ta xartfá $t \quad c e$

open.PST.3SG DEF.PL.ACC paper.PL.ACC 3SG.ACC and

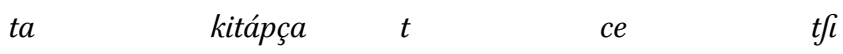

DEF.PL.ACC book.PL.ACC 3SG.ACC and what

kitápça erjó sernicí dén bórinan

book.PL.ACC two man.PL.NOM NEG can.PST.IMPF.3PL

na ta fikósun. drána ja

COMP 3PL.ACC lift.PNP.3PL look.IMPV.2SG EXCL

útfayadáris mejála kitápça c c éna

so_much big.PL.NOM book.PL.NOM and INDF

kánona den ivre $s \quad$ etó

rule.sG.ACC NEG find.PST.3SG LOC PROX.SG.ACC

to óryo

DEF.SG.ACC work.SG.ACC

'He opened his papers and his books - and what books! Two men could notlift them up. And see? Such big books and he did not find one rule for this job.'

These data support Dawkins's (1916) early analysis of Cappadocian and Pharasiot DCM as being determined by definiteness, a view that was later adopted by Janse (2004), Spyropoulos and Kakarikos (2009), Alexiadou and Kornfilt (2010), and Spyropoulos (2016). Therefore, in terms of the Definiteness Hierarchy (5), the cut-off point for overt direct object marking in iAMG R lies between definite NPs and indefinite specific NPs with all NPs whose definiteness values fall to the left of the point bearing accusative marking (Fig. 2).
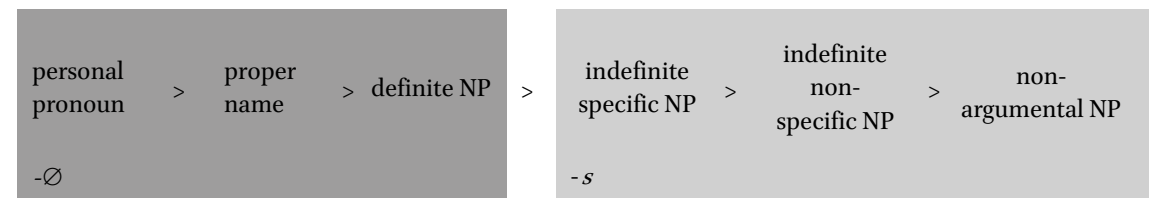

FIGURE 2 DCM in iAMGr. 
Similarly to the ModGr state of affairs described in 3.1, only nouns belonging to ICs that are synchronically or diachronically associated with the masculine gender distinguish morphologically between the two core cases in the singular their inflectional paradigms. As far as Cappadocian is concerned, this holds for ICs 1, 2, and 3; see Table 2.

TABLE 2 The Cappadocian inflectional classes. Brackets indicate vowels that are dropped due to the phonological process of unstressed high vowel deletion that operates in Cappadocian. The tilde indicates cells that display interdialectal variation. ICia only contains animate nouns, IClb is only composed of inanimate nouns. Similarly, only human nouns belong to IC3a whereas only non-human nouns belong to $\mathrm{IC}_{3} \mathrm{~b}$. The distinction between $\mathrm{IC}_{4} \mathrm{a}$ and $\mathrm{IC}_{4} \mathrm{~b}$ is based on stem allomorphy.

\begin{tabular}{|c|c|c|c|c|}
\hline & & ICra & IClb & \\
\hline \multirow[t]{3}{*}{ SG } & NOM & áӨropo-s 'man' & mílos 'mill' & \\
\hline & ACC & 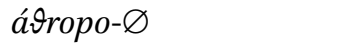 & mílo- $\varnothing$ & \\
\hline & GEN & $a \vartheta$ róp $(-u) \sim a \vartheta r o p-i n u ́$ & míl $(-u) \sim$ mil-inú & \\
\hline \multirow[t]{4}{*}{ PL } & NOM & $a \vartheta r o ́ p(-i)$ & míl-us & \\
\hline & ACC & 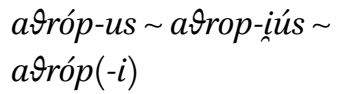 & míl-us & \\
\hline & GEN & 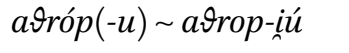 & míl(-u) mil-iún & \\
\hline & & $\mathrm{IC} 2$ & $\mathrm{IC}_{3} \mathrm{a}$ & $\mathrm{IC}_{3} \mathrm{~b}$ \\
\hline \multirow[t]{3}{*}{ SG } & NOM & kléfti-s 'thief' & papá-s 'priest' & ceratá-s 'snail' \\
\hline & ACC & kléft $(i)-\varnothing$ & papá-Ø & ceratá- $\varnothing$ \\
\hline & GEN & kleft-iú & рара́- $\varnothing \sim$ рараð-i्nú & ceratað-iñ \\
\hline \multirow[t]{4}{*}{ PL } & NOM & kléft(-i) & papáð-es papáð(-i) & ceratád-ia \\
\hline & ACC & kleft-iús & papád-es papað-iús & ceratád-ịa \\
\hline & GEN & kleft-iú & papað-iú & ceratað-iú \\
\hline & & IC4a & $\mathrm{IC}_{4} \mathrm{~b}$ & \\
\hline \multirow[t]{2}{*}{ SG } & NOM/ACC & néka 'woman' & niff(i) 'bride' & \\
\hline & GEN & néka-s & nífi-s nifað-iúu & \\
\hline \multirow[t]{3}{*}{ PL } & NOM/ACC & néc-es & níf-es nifád-es & \\
\hline & GEN & nek-ón & nif-iú & \\
\hline & & $\mathrm{IC}_{5}$ & IC6 & $\mathrm{IC}_{7}$ \\
\hline \multirow[t]{2}{*}{$S G$} & $\mathrm{NOM} / \mathrm{ACC}$ & xtin-ó 'cow' & fti 'ear' & spit 'house' \\
\hline & GEN & 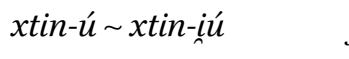 & $f t \underline{i}-\dot{u}$ & spit-iú \\
\hline \multirow[t]{2}{*}{$\mathrm{PL}$} & NOM/ACC & $x t i n-a ́ a x t i n-i a_{a}$ & fti-á & spít-ia \\
\hline & GEN & $x$ tin-ú $\sim x t i n-i u^{u}$ & fti-ú & spit-iú \\
\hline
\end{tabular}


TABLE 2 The Cappadocian inflectional classes. Brackets indicate vowels (cont.)

\begin{tabular}{llll}
\hline & & IC8 & IC9 \\
SG & NOM/ACC & pará 'money' & púma 'cover' \\
& GEN & parað-iń & pumát(-u) \\
PL & NOM/ACC & paráð-ina & púmat-a \\
& GEN & parað-iń & - \\
\hline
\end{tabular}

As shown in the table, in Cappadocian, too, the distinction correlates with the presence or absence of -s. Compare, in that connection, xazná-s with xazná- $\varnothing$ in (16), and tópo-s with tópo- $\varnothing$ in (20).

The situation in the plural of the historically masculine ICs is slightly different. As can be seen in Table 2, Cappadocian exhibits variation with respect to the marking of nominative and accusative plural. In ICs $1 b$ and 3 b, the two are syncretic across all varieties: in ICıb, the inherited accusative plural suffix -us is used for both case/number combinations, whereas in $\mathrm{IC}_{3} \mathrm{~b}$ it is the $\mathrm{IC}_{7}$ nominative/accusative suffix - $i a$ that assumes this function. The same holds for ICs 1a and za in the majority of Cappadocian varieties: in IC1a, the nominative and accusative plural are syncretically marked by the inherited nominative plural suffix $-i$, whereas in IC 3 a this is done by either by the inherited nominative plural suffix -es or by -i. However, the varieties of Delmesó, Potámia, Malakopí, Axó, and Mistí preserve the morphological distinction between the two cases so that the nominative plural is marked by $-i$ (ICs 1a, 2, 3a) or -es (IC3a) and the accusative plural is marked by -us (IC1a) or -iús (IC1a, 2, 3a). It is interesting, though, that, despite the availability of this morphological material, DCM of the type that was exemplified in (16)-(20) above with nouns in the singular does not apply in the plural. Consider the examples in (26) and (27). In the Axó example in (26), the accusative plural suffix -iús marks both misefiriús (26a), which is the head noun of a definite NP, and asceriús (26b), which is the head noun of an indefinite NP. In the Malakopí example in (27), the inherited nominative plural suffix $-i$ marks the head noun of a definite NP.

(26) Axó Cappadocian (Mavrochalyvidis and Kesisoglou, 1960: 190, 202)

$\begin{array}{lllll}\text { a. } \quad & \text { misefiriús }=u m & m e & \text { to } & \\ \text { DEF.PL.ACC } & \text { guest.PL.ACC=1SG.GEN } & \text { COM } & \text { DEF.SG.ACC } & \\ \text { kaló } & n a & t a & \text { pári } & \text { apéso } \\ \text { good.sG.ACC } & \text { COMP } & \text { 3PL.ACC } & \text { take.PNP.3SG } & \text { INT } \\ \text { '...that he receives my guests nicely' } & & & \end{array}$




$\begin{array}{lllll}\text { b. } & \text { vafiKós } & \text { joliadúz } & \text { djo asceriús } & \text { na } \\ \text { king.SG.NOM } & \text { send.PRS.3SG } & \text { two soldier.PL.ACC } & \text { COMP } \\ \text { kópfne } & \text { to } & \text { kfilo } & & \\ \text { cut.PNP.3PL } & \text { DEF.SG.ACC } & \text { tree.SG.ACC } & \end{array}$

'The king sends two soldiers to cut the tree.'

(27) Malakopí Cappadocian (Dawkins, 1916:408)

\begin{tabular}{|c|c|c|c|c|}
\hline$i f^{\prime}$ & $p \operatorname{ços}$ & $i$ & deji $\quad c i$ & skotóns \\
\hline 2SG.NOM & who.sG.NOM & COP.PRS.2SG & QUOT & kill.PRS.2SG \\
\hline$t a$ & a৩róp $(-i)$ & & & \\
\hline
\end{tabular}

In Pharasiot ICs corresponding to Cappadocian ICs 1, 2, and 3, the nominative and accusative plural are always syncretically marked by $-i$ (ICs 1 and 2 ) and $-e(s)$ (IC3); see Dawkins (1916: 163-170). DCM in iAMGr is, therefore, operative only in the singular of synchronically or diachronically masculine nouns.

In the case of nouns belonging to synchronically or diachronically feminine and neuter ICs (4, and 5, 6, 7, and 8, respectively), nominative and accusative are syncretic and always expressed by a single form in both numbers and in both dialects.

Even more limiting to the morphologial expression of DCM is the collapse of the originally distinct masculine, feminine, and neuter forms of agreement targets (articles, adjectives, pronouns, participles, numerals) into a single, historically neuter form that we find in all AMGr dialects (Karatsareas 2009, 2011, 2014). Owing to this reduction and, in certain cases even complete loss, of grammatical gender, the differential distinction between definite and indefinite NPs is effectively evident by means of accusative and nominative marking mostly on head nouns of NPs. In the Cappadocian example in (28), the indefinite article and the modifying adjective appear in the historical neuter forms éna and álo and not in the historical masculine forms énas and álos despite the fact that they agree with the historical masculine noun numatfis. See also the forms of the indefinite article in (16a) and (20a), and of the modifying adjectives in (16a) and (20b).

(28) Araván Cappadocian (Fosteris and Kesisoglou, 1960: 102)

$\begin{array}{llll}\text { sálse } & \text { éna } & \text { álo } & \text { numátfis } \\ \text { send.IMPV.2SG } & \text { INDF } & \text { other.sG.ACC } & \text { man.sG.NOM } \\ \text { 'Send another man.' } & & \end{array}$


In Pharasiot, however, as well as in the Cappadocian varieties of Delmesó, Potámia and Sílata the tripartite gender distinction is preserved on the definite article which additionally shows agreement for number and case; see (16b) and (2ob).

\subsection{Emergence}

It is not unheard of from a diachronic point of view for an originally nondifferential language to develop into a differential one language-internally, that is, without the influence of a contact language. A number of Romance languages that developed out of non-differential Vulgar Latin-most notably, Spanish, Catalan and Sardinian-are differential, as are most Slavonic languages and Hebrew, having evolved from non-differential Proto-Indo-European and Proto-Semitic, respectively (for the Romance languages and Hebrew, see Bossong, 1991; Guardiano, 2010; Melis and Flores, 2009; for the Slavonic languages, see Corbett 1991: 98-99; Igartua, 2005: 478-592; Klenin, 1983).

From that point of view, the possibility that DCM in Cappadocian and Pharasiot may have emerged through language-internal processes should not-in principle-be excluded in spite of the fact that all other known ModGr dialects are non-differential, making the Cappadocian and Pharasiot developments seem of a rather 'un-Greek' nature. As a matter of fact, Andriotis (1948: 47), Mavrochalyvidis and Kesisoglou (1960: 82) and Anastasiadis (1976: 94-96) identified a number of language-internal factors that, they argue, gave rise to DCM in iAMGr: Andriotis sees DCM as an analogical extension of nominative/ accusative syncretism from the plural to the singular (see Table 1); Mavrochalyvidis and Kesisoglou treat it as a corollary of the loss of grammatical gender distinctions; and, Anastasiadis suggests that what is at play in iAMGr is the diachronic tendency of many Indo-European languages to reduce the number of morphologically expressed cases combined with the primacy of the nominative case within the inflectional paradigm of ModGr nouns. These proposals, however, fail to account for the fact that nominative/accusative syncretism is systematically found only in indefinite contexts and not in definite ones. In this light, Dawkins's (1916) early proposal that DCM in Cappadocian and Pharasiot developed as a result of contact with Turkish is the strongest hypothesis formulated to date, despite its lack of detailed argumentation.

The most compelling piece of evidence in favour of a contact explanation for the development of DCM in iAMGr is the typological unlikelihood of its synchronic implementation. Previous work on differential argument marking systems of the asymmetric type, DOM in particular, has shown that "overwhelmingly, DOM is implemented by overtly marking the marked class of objects and leaving the unmarked ones with no morphological mark" (Aissen, 
2003: 446, emphasis in the original; see also Bossong, 1985; Comrie, 1989; Croft, 2003). Markedness in the case of objects is understood in terms of semantic (proto)typicality the idea being that, crosslinguistically, (proto)typical objects tend to be indefinite, inanimate, and rhematic (Comrie, 1979: 19). From that point of view, an indefinite (and inanimate and rhematic) object is considered unmarked whereas a definite (and animate and thematic) object is considered marked (Comrie, 1989: 128; see also Battistella, 1990; Croft, 2003; Keenan, 1976). The way Aissen understands morphological markedness is not entirely clear. It seems, however, to be grounded on a very basic conceptualisation of morphological complexity whereby the more segments and/or syllables a given marker consists of the more complex it is; cf. Stolz et al.'s (2014: 22-30) discussion of the morphological complexity of spatial markers. A marker consisting of two phonological segments is therefore more complex and more marked than a marker consisting of one phonological segment, which is in turn more complex and more marked than a zero marker.

Aissen's generalisation is borne out both by languages that are known to have always been differential in their history, such as Turkish, and by languages that developed Dом at some point in their recorded history, such as Hebrew. ${ }^{8}$ Recall from Sections 2 and 3.2 that, in Turkish, only direct object NPs with specific referents are marked by $-(y) I$; non-specific NPs remain zero-marked. In Hebrew, et only precedes definite object NPs, indefinite ones bearing no overt marking. Both DOM patterns are consistent with Aissen's prediction that "if a language case marks any objects, it will case-mark definite ones. A language may mark specific objects, and leave non-specific ones unmarked. But no language will case-mark specific indefinites, but not definites" (2003: 456). Along similar lines, Croft argues that "if a language uses a nonzero case marking for a $\mathrm{P}$ [atient] argument on the animacy/definiteness hierarchies, then it uses a nonzero case marking for P arguments higher on the hierarchies" (2003: 166).

8 According to one reviewer, Tekin (1968: 127-130) lists a number of examples from the Orkhon Turkic inscriptions ( 7 th-8th century ce) whereby direct object NPs that take a specific reading are zero-marked and direct object NPs that take a non-specific reading are marked by the accusative. Such cases clearly challenge both Aissen's (2003) generalisation and my claim that Turkish has always been a differential language. Erdal (2004: $362-363,366)$, however, only finds zero-marked specific objects in the historical record and no objects that are non-specific and marked by the accusative. He states that, on the basis of the available data, "[w]e are at present unable to state any rule in this matter" (2004: 366). The issue clearly needs further investigation, not least in order to test the validity of Aissen's (2003) and Iemmolo's (2013) robust crosslinguistic generalisations about DOM. 
These observations are schematically illustrated by Turkish and Hebrew in Fig. 3 .

\begin{tabular}{|c|c|c|}
\hline \multirow{3}{*}{ Turkish } & Semantic markedness & Formal markedness \\
\hline & specific & $-(y) I$ \\
\hline & non-specific & $-\varnothing$ \\
\hline \multirow{2}{*}{ Hebrew } & definite & et \\
\hline & indefinite & $-\varnothing$ \\
\hline
\end{tabular}

FIGURE 3 Markedness relations in Turkish and Hebrew DOM. Dark cells indicate marked options, light cells indicate unmarked ones.

The iAMGr DCM pattern violates Aissen's, Comrie's and Croft's generalisations. In Cappadocian and Pharasiot, the $-s$ suffix is found on the head nouns of indefinite NPs while the zero suffix occurs with definite NPs. In other words, the overt, morphologically more complex element involved in the morphological distinction employed for the formal implementation of DCM marks the unmarked class of objects while the marked class of objects are zero-marked and therefore morphologically simpler than their semantically unmarked counterparts. See Fig. 4.

$\begin{array}{ccc} & \text { Semantic markedness } & \text { Formal markedness } \\ & \text { definite } & -\varnothing \\ \text { iAMGr } & \text { indefinite } & -s\end{array}$

FIGURE 4 Markedness relations in iAMGr DCM. Dark cells indicate marked options, light cells indicate unmarked ones.

This violation casts doubt on any hypothesis that would treat the emergence of DCM in iAMGr as an instance of language-internal change. If this had been the case, the expected implementation would have required forms ending in $-s$ to be used for definite NPs and zero-marked forms to be used for indefinite NPs. For instance, with reference to the examples in (15)-(19), we would expect to

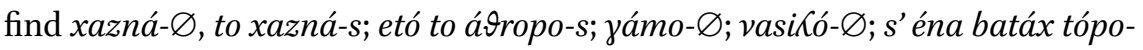
$\varnothing$, so filan son tópo-s.

The typologically deviant means employed for the expression of DCM in Cappadocian and Pharasiot can be accounted for by comparing the iAMGr pattern with Dом in Turkish. Particularly illuminating in that connection is the relation between the case form used for the head nouns of the unmarked class of NPs in DCM/DOM and that found in the head nouns of subject NPs in the three languages. In Cappadocian and Pharasiot, head nouns of indefinite NPs 
and those of subject NPs appear in the same form, namely, the nominative; compare the examples in (29) and (30). The exact same relation holds in Turkish between the forms of head nouns in non-specific direct object NPs and subject NPs as they both occur in the same, zero-marked form (31). ${ }^{9}$

(29) Phloïtá Cappadocian (Tsitsopoulos, 1962: 54, 58)

a. direct object NP

$\begin{array}{lllll}\text { jolátsan } & \text { éna } & \text { á } \text { ropos } & n a & \text { to } \\ \text { send.PST.3PL } & \text { INDF } & \text { man.SG.NOM } & \text { COMP } & \text { 3SG.ACC } \\ \text { tfijirtíf } & & & & \\ \text { call.PNP.3SG } & & & & \end{array}$

'They sent out a man for him.'

b. subject NP

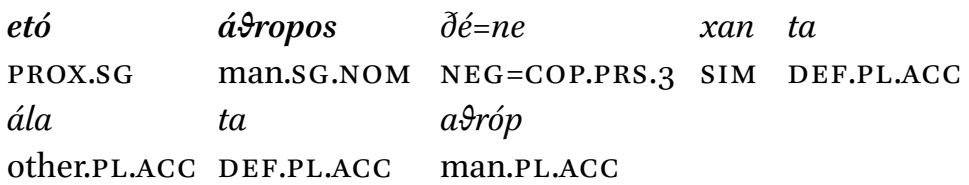

'This man is not like other men.'

(30) Pharasiot (Dawkins, 1916:474, 476)

a. direct object NP

$\begin{array}{lllll}\text { ifen } & t \int e & i & n e ́ k a & a \\ \text { have.PST.3SG } & \text { and } & \text { DEF.F.SG.NOM } & \text { woman(F).SG.NOM } & \text { INDF } \\ \text { yaríxos } & & & & \\ \text { lover(M).SG.NOM } & & & \end{array}$

'And the woman had a lover.'

9 In addition to the dom system, Turkish also has a differential subject marking system, which operates in embedded nominalised clauses, so that specific subjects are marked by the genitive as in (i) whereas non-specific subjects are zero-marked as in (ii):

(i) Turkish (Kornfilt, 2009: 84)

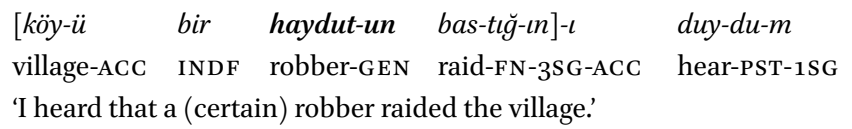

(ii) Turkish (Kornfilt, 2009: 84)

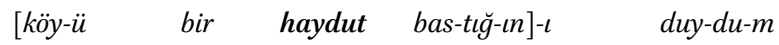

village-ACC INDF robber raid-FN-3SG-ACC hear-PST-1SG

'I heard that a robbers raided the village.'

For detailed analyses of this alternation, which challenges Aissen's (2003) proposed analysis of dsm as a mirror-image implementation of the principles that govern dom, see Kornfilt (1984, 1997, 2009) and von Heusinger (2005). 
b. subject NP

\begin{tabular}{|c|c|c|c|}
\hline ¿əen & $o$ & yaríxos & $t i$ \\
\hline $\begin{array}{l}\text { see.PST.3SG } \\
\text { néka }\end{array}$ & DEF.M.SG.NOM & lover(M).SG.NOM & DEF.F.SG.ACC \\
\hline
\end{tabular}

(31) Turkish

a. direct object NP

$\begin{array}{llll}\text { Yasemin- } \varnothing & \text { bir } & \text { anahtar- } \varnothing & \text { kaybet-ti. } \\ \text { PN } & \text { INDF } & \text { key } & \text { lose-PST }\end{array}$

'Yasemin lost a key.'

b. subject NP
Anahtar- $\varnothing$
paspas-ın
alt-ın-da.
key
doormat-GEN bottom-POSS.3SG-LOC
'The key is under the doormat.'

DCM in Cappadocian and Pharasiot therefore contrasts sharply with the overwhelming majority of DCM systems attested crosslinguistically precisely because it developed in the model of Turkish Doм.

This conclusion finds additional support in the low probability that genetic inheritance might be responsible for the occurrence of DCM in the two iAMG $r$ dialects. As argued by Karatsareas (2011, 2013), the linguistic innovations that Cappadocian and Pharasiot share do not suggest a strong link of genetic relatedness between the two. There is not enough evidence that the two dialects once formed an independent, linguistically uniform branch within the wider AMGr dialect group, and the occurrence of DCM in both should not be considered as pointing towards such a subgrouping. Rather, the identical Cappadocian and Pharasiot DCM patterns should be viewed as two instances of the same contact-induced development that lack historical value. Consider, in that connection, the caveat expressed by Dawkins: "[the AMGr dialects] are very strongly under Turkish influence, and this cause may be supposed to produce everywhere the same effects. A Turkism common to two or more of the dialects has therefore no value as a mark of historical relationship" (1916: 204).

Along the same lines, I argue that the similarity between Cappadocian and Pharasiot DCM does not trace its origin to a common development of the two dialects. In contrast, I view it as a case of areal convergence whereby Cappadocian and Pharasiot underwent the same grammatical innovation under the 
common influence of Turkish within a single linguistic micro-area, in which the three languages were contiguously spoken (in the sense of Heine and Kuteva, 2005: 177-178; see also Aikhenvald, 2007: 11-15; Aikhenvald and Dixon, 2001: 2, 11-19; Campbell, 2006; Matras, 2009: 265-274; Stolz, 2006; Thomason and Kaufman, 1988: 95-97). Within this micro-area, the two iAMGr dialects acquired a novel common trait that they previously did not share and which differentiates them from the other dialects of the same dialect group (Silliot, Pontic, Crimeoazovian).

Heine and Kuteva (2005: 183) distinguish between two possible pathways developments of this kind may follow: one of the two AM Gr dialects develops DCM as a result of contact with Turkish and subsequently serves as the model for the other dialect to undergo the same innovation; or, alternatively, both dialects develop DCM independently, but in similar fashions owing to the same original accusative-neutral system and the same Turkish model. Like most instances of areal developments discussed by Heine and Kuteva (2005: 182-218), the available data on iAMGr do not allow us to determine unambiguously which of the two pathways was followed in our case. In contrast to many cases of areal diffusion, however, we are in a position to identify Turkish as the model language and Cappadocian and Pharasiot as the replica languages in Heine and Kuteva's terminology.

Regardless of the borrowing pathway, it is clear that the two iAmGr dialects replicated the Turkish Dом pattern without borrowing any of the linguistic material used for its implementation in Turkish, namely the - $(y) I$ suffix that marks specific direct object NPs. Rather, the originally non-differential case marking system of ModGr was adapted to the model of Turkish DOM using material already available in Greek. We are therefore dealing with a case of pattern replication in the sense of Matras and Sakel (2007) or of selective copying in the sense of Johanson (1999, 2002).

In replicating Turkish Dом, Cappadocian and Pharasiot drew upon their existing grammatical resources to establish (a) the referential property that would determine which NPs would be overtly marked and which ones would be left unmarked in the contexts in which DCM would be active; and, (b) the formal means for the implementation of the DCM pattern. With respect to the former, Turkish specificity was matched with Greek definiteness, which was the most relevant referential property that was already morphosyntactically expressed in the grammatical system of the two iAMGr dialects by means of the definite and indefinite articles. The outcome of the matching was that definite and indefinite NPs in Cappadocian and Pharasiot were taken to correspond to specific and non-specific NPs in Turkish, respectively. The novel differential 
distinction was subsequently formally realised by matching Turkish zero marking with the Greek nominative by virtue of the fact that they were both used to mark subject NPs in the languages involved, and the Turkish accusative with the Greek accusative by virtue of the fact that both mark the head nouns of direct object NPs. The replication is summarised in Fig. 5 .

$\begin{array}{lll} & \text { Turkish } & \text { iAMGr } \\ \text { Referential } & \text { SPECIFICITY } & \| \text { DEFINITENESs } \\ \text { property } & {[+ \text { specific }]} & \|[+ \text { definite }] \\ & {[- \text { specific }]} & \| \quad[- \text { definite }] \\ & \text { non-specific } \Rightarrow \text { zero-marked }(-\varnothing) & \| \quad \text { indefinite } \Rightarrow \text { nominative }(-s) \\ \text { Formal marking } & & \\ & \text { specific } \Rightarrow \text { zero-marked }(-(y) I) & \| \quad \text { definite } \Rightarrow \text { accusative }(-\varnothing)\end{array}$

FIGURE 5 Pattern replication in iAMGr.

The Cappadocian and Pharasiot data do not allow us to conclude with safety whether DCM applied first to some types of direct object NPs and spread to others at a later stage or whether it applied instantly to all of the syntactic contexts identified in 4.1. A hypothesis, however, can be formulated by examining the very few cases of DCM that are attested in Silliot, the third member of the iAMGr group. In his description of the dialect, Kostakis mentions that " $\alpha \nu \tau i$

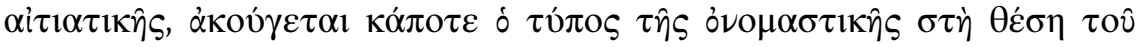

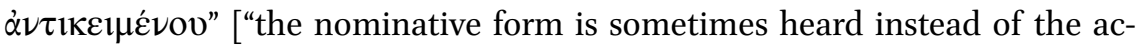
cusative in the object position"] (1968: 104), providing the example in (32); see

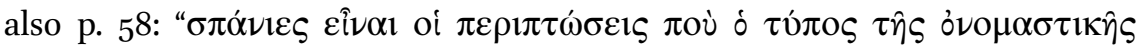

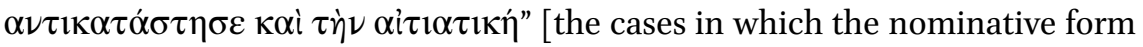
has replaced the accusative are rare]).

(32) Silliot (Kostakis, 1968: 104)

$\begin{array}{llll}\text { na } & \text { mas } & \text { pis } & \text { ajazmós } \\ \text { COMP } & \text { 1PL.GEN } & \text { do.PNP.3SG } & \text { sanctification(M).SG.NOM } \\ \text { 'that he performs a sanctification for us' } & \end{array}$

Nominative marking on ajazmós contrasts with accusative marking, which is typical for Silliot across-the-board and in all the relevant syntactic positions in which DCM is operative in Cappadocian and Pharasiot regardless of definiteness. Compare (32) with (33). 
(33) Silliot (Kostakis, 1968: 128)

$\begin{array}{llll}\text { kostadínos } & \text { píci } & \text { ajazmó } & t / \text { } \\ \text { PN(M).SG.NOM } & \text { do.PST.3SG } & \text { sanctification(M).SG.ACC } & \text { DEF.F.SG.ACC } \\ \text { klifá } & \text { mas } & \\ \text { church(F).SG.ACC } & \text { 1PL.GEN } & \\ \text { 'Konstantinos performed a sanctification at our church.' }\end{array}$

The phenomenon is clearly marginal in this dialect. Dawkins does not mention it in his 1916 nor are any examples found in the Silliot texts that he documents (1916: 284-304). Kostakis's is the only relevant mention, no occurrences are found in his texts (1964:116-130), and he also notes that nominative marking of the type shown in (32) is very rare. It is, however, indicative that (32), which is the only example that he adduces, involves a light verb construction formed with ftfánu 'do'; cf. also the Cappadocian light verb construction in (18). As one of the reviewers points out, this type of construction bears semantic similarities with noun incorporation of the Turkish type exemplified in (14e). Crucially, nouns occuring in Turkish incorporating constructions are always zeromarked and can never carry the accusative $-(y) I$ suffix. It can therefore be proposed based on the Silliot data that light verb constructions were the environment in which nominative marking first became possible in iAMGr in the model of Turkish incorporating constructions. Nominative marking was subsequently extended from this low end on the Definiteness Hierarchy to other positions until it reached the indefinite specific NP-definite NP cut-off point. It should be noted in that connection that DCM as seen in positions other than in direct objects and light verb complements (indirect objects, object predicatives, adpositional complements, temporal adjuncts) cannot be considered to be the outcome of replication of Turkish patterns as Turkish does not display any case alternations in these contexts. The spread of the nominative-accusative alternation to these positions should therefore be considered a languageinternal development of the iAMGr dialects.

This hypothesis is naturally based on the assumption that Silliot replicated nominative marking in this historically accusative-marked position independently and similarly to the way in which Cappadocian and Pharasiot were argued to have replicated their full-fledged DCM systems. Given the very rare occurrences of nominative marking in the available Silliot data and the most extensive and regular use of the accusative, it would not be parsimonious to hypothesise that, at some earlier point in its history, Silliot developed a DCM system out of an accusative-neutral one and then reverted to an almost regular accusative-neutral system. In any case, it is not extraordinary to propose that 
the innovation first concerned only a subset of environments traditionally marked by the accusative in Greek and only later extended to additional syntactic contexts.

Note, however, that the correspondence between (in)definite NPs in Cappadocian and Pharasiot, and (non-)specific NPs in Turkish was not complete as the semantic intepretations of definiteness and specificity do not coincide. As was mentioned in Section 2, while the referents of definite NPs in principle take a specific reading, those of indefinite NPs may be interpreted as either specific or non-specific. Owing to this relation between the two referential properties, accusative marking in Turkish occurs with both definite and indefinite NPs while, in Cappadocian and Pharasiot, accusative marking is only found with definite NPs. Zero marking in Turkish is limited to non-specific indefinite NPs, while, in the two iAMGr dialects, nominative marking is found with all indefinite NPs irrespective of whether they have a specific or nonspecific reading. This discrepancy is schematically illustrated in Fig. 6.

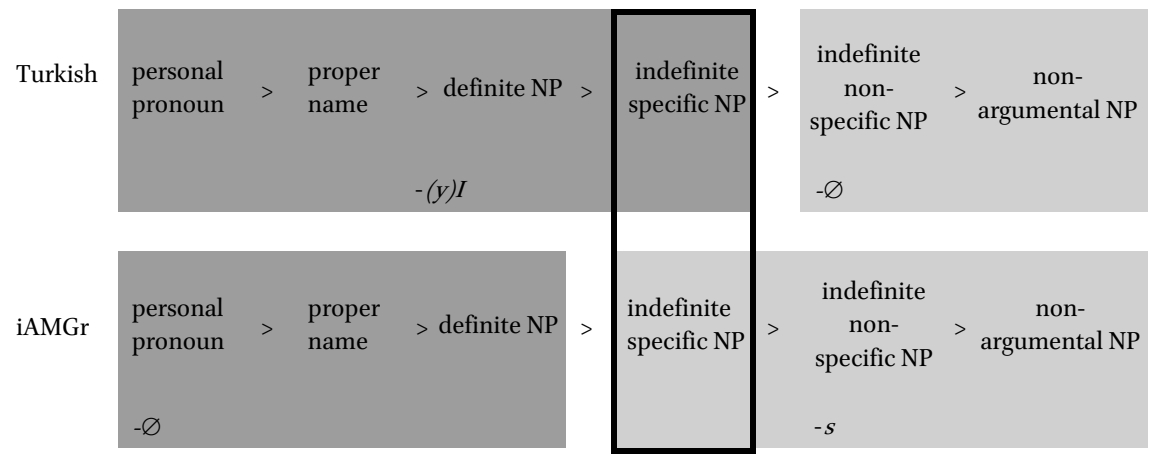

FIGURE 6 Turkish DOM and iAMGr DCM in contrast.

As shown in the figure, however, the difference between the specificity-based DoM pattern of Turkish and the definiteness-based DCM pattern of Cappadocian and Pharasiot is not great and in effect only concerns the marking of specific indefinite NPs.

4.2.1 Cappadocian and Pharasiot DCM, and Pontic DSM: two sides of the same coin?

In Pontic, masculine head nouns of subject NPs are marked by the nominative only when they are preceded by the indefinite article (34a) or when they appear bare; when preceded by the definite article, they are marked by the accusative (34b) (Koutita-Kaimaki, 1977/1978). This, however, does not apply to all masculine nouns but only to those that end in -os in the nominative singular; cf. ICı nouns in ModGr. 
(34) Kerasoúnta Pontic (Lianidis, 2007 [1962]: 142)

a. érve

énan

iméran

énas

come.PST.3SG

INDF.N.SG.ACC

$\operatorname{day}(\mathrm{F})$. SG.ACC

INDF.M.SG.NOM

kalójeros $s u$

plúsionos

monk(M).SG.NOM LOC.DEF.M.SG.GEN rich.M.SG.GEN

'One day, a monk came to the rich man's house.'

b. epíjen

go.PST.3SG

o

kalójeron

son

áin

DEF.M.SG.NOM

$\operatorname{monk}(\mathrm{M}) . \mathrm{SG} . A C C$

LOC.DEF.M.SG.ACC

holy.M.SG.ACC tomb(M).SG.ACC

'The monk went to the Holy Sepulchre.'

It would therefore appear that Pontic has a Differential Subject Marking (henceforth DSM) system whereby definiteness determines the case marking of at least some nouns found in the subject position in the same way that it determines the case marking of nouns found, among others, in the object position in Cappadocian and Pharasiot. ${ }^{10}$ Based on this similarity, Dawkins (1916: 94) drew a parallel between the two phenomena arguing that they constitute reflexes of an early innovative association between case and the expression of definiteness so that the accusative became associated with [+definite]

10 What conditions dsm in Pontic is a matter of debate in the literature. Hatzidakis (1934 [1911/1912]: 276), Tompaidis (1980: 224, 1988: 45-46), and Oikonomidis (1958: 145) have claimed that it is conditioned by the overt versus null realisation of the definite article so that masculine head nouns of subject NPs appear in the accusative case when preceded by an overtly realised definite article and in the nominative elsewhere. There are, however, counterexamples such as (i):

(iii) Pontic (Koutita-Kaimaki, 1977/1978: 282)

$\begin{array}{lllll}\text { epróftasen } & \text { eceká } & a^{n} \text { felon } & \text { ce ipen } & \text { atón } \\ \text { catch_up.PST.3SG } & \text { DIST } \text { angel(M).sG.ACC } & \text { and } & \text { tell.PST.3SG } & \text { 3SG.ACC } \\ \text { 'The angel caught up with him and said to him...' } & & \end{array}$

Papadopoulos (1955: 30) has claimed that dsm is determined by the syntactic position of the NPs in which masculine nouns are found. In his view, accusative marking is found in the subject position whereas nominative marking is found in the predicate position. The evidence in (30a), however, challenges this account. More recently, Revithiadou and Spyropoulos (2009: 52-53, 60-61) have questioned the analysis of the Pontic phenomenon as a case of dsm, mainly on the grounds that it is limited to a subset of masculine nouns and does not apply to other groups of nouns that retain the morphological distinction between nominative and accusative in the singular such as masculine nouns that end in -is, -as or -es or to feminine nouns. They suggest that we might be dealing with a case of a morphologically restricted, definiteness-based syncretism of the two core cases, nominative and accusative. In support of this proposal, we might add the fact that it is only the 
and the nominative with [-definite]. This is postulated to have taken place before the three dialects started to develop idiosyncratically. In a recent study, Spyropoulos (2016) restates this hypothesis and proposes that the common thread that unites Pontic DSM and Cappadocian and Pharasiot DCM can be found in language contact between the AMGr dialects and Turkish either bilaterally or more widely within an anatolian Sprachbund context, citing Tzitzilis (1989) in that connection.

However, in order for a common origin for the two phenomena to be postulated from a historical point of view, all three AMGr dialects would have to share a (quasi-)identical or at least similar DCM pattern-or reflexes of itthat could be unambiguously identified as such either in accusative- or in nominative-marked contexts, or in both. However, none of these possibilities are consistent with the available data. On the one hand, a DCM pattern similar to that of Cappadocian and Pharasiot cannot be established for Pontic, which is non-differential with respect to typically and historically accusative-marked positions. Like the overwhelming majority of ModGr dialects, Pontic uniformly marks the head nouns of NPs found in such positions with the accusative (Drettas, 1997; Papadopoulos, 1955: 159-16o). On the other hand, the Cappadocian and Pharasiot data do not provide evidence of a DSM pattern. There do exist a small number of examples in which accusative-like forms are found in subject position in Cappadocian. In (35a), koikonó is formally identical with the accusative singular form; similarly, in (35a), vafíó looks like an accusative singular. However, if we compare ( $35 \mathrm{a})$ with $(35 \mathrm{~b})$, we can see that definiteness plays no role in conditioning the form of the head noun of the subject NP and can infer that, in cases such as this, we are probably dealing with some type of morphological change that has shifted koikonos from the IC of historical masculine nouns ending in -os to the IC of historical neuter nouns ending in -o, which do not distinguish formally between the nominative and the accusative. The comparison of ( $36 \mathrm{a})$ with $(36 \mathrm{~b})$ shows that the seemingly accusative form vafiKó is probably the result of a phonological process of cluster simplification (vafíós + mas $\longrightarrow$ vafíó mas; see also Spyropoulos and Tiliopoulou, 2006: $372)$. For the analysis of a few more types of examples such as (35a) and (36a), see Karatsareas (2011: 110-115).

masculine head nouns of subject NPs that appear in the accusative form in definite contexts while other nominal elements (definite articles, modifying adjectives and pronouns) appear in the nominative form, as expected; compare, for example, accusative marking on kalójeron in (3ob) but nominative marking on the definite article o. For a rather different approach, see Drettas (1999). 
(35) Axó Cappadocian (Dawkins, 1916:400, 402)

a. cíton éna koikonó c

$\begin{array}{ll}\text { be.PST.IMPFV.3SG } & \text { INDF cockerel.SG.NOM and } \\ \text { éksen } & \text { píjen } \\ \text { go_out.PST.3SG } & \text { go.PST.3SG }\end{array}$

'There was a cockerel, and it went out and away.'

b. ksévalen to koikonó to

put_down.PST.3SG DEF.SG.NOM cockerel.sG.NOM DEF.SG.NOM

liko

wolf.s G.ACC

'The cockerel put down the wolf.'

(36) Phloïtá Cappadocian (Tsitsopoulos, 1962: 79, 8o)

a. krev se vafiKó mas na se

look_for.PRS.3SG 2SG.ACC king.SG.NOM 1PL.GEN COMP 2SG.ACC

ðiciví

marry.PNP.3SG

'Our king is looking for you to marry you.'

b. vafiKós pále tfüirtá to peði

king.SG.NOM again call.PRs.3Sg def.sG.ACC boy.sG.ACC

'The king calls for the boy again.'

In short and on the basis of the above, I argue that, despite their apparent similarities, a connection between Cappadocian and Pharasiot DCM and Pontic DSM cannot be supported by concrete evidence. The two should therefore be treated as independently-motivated and unrelated developments.

\subsection{Preservation and Loss}

In Pharasiot, the application of DCM is exceptionless and is preserved in the dialect to the present day. In Cappadocian, on the contrary, a non-negligible number of instances are found in which the case alternation pattern described in the previous sections is not adhered to. These specifically involve definite NPs that are marked by the nominative and not by the accusative as would be expected given the fact that they appear in one of the syntactic positions in which DCM is operative. Examples of such deviant marking are found with both animate and inanimate nouns in all Cappadocian varieties. See (37). 
(37) a. Ghúrzono Cappadocian (Dawkins, 1916: 344) os to perpénifce qarfuláte

while 3SG.ACC bring.PST.IPFV.3SG meet.PST.3SG

to kléft fis

DEF.SG.ACC robber.SG.NOM

'While he was bringing her, he met the robber.'

b. Mistí Cappadocian (Kostakis, 1959: 82)

vovóntan

na pan

be_afraid.PST.IPFV.3PL COMP go.PRS.3PL

su

mílus

LOC.DEF.SG.ACC

mill.sG.NOM

'They were afraid to go to the mill.'

c. Ferték Cappadocian (Dawkins, 1916: 330)

ta spítça írtan pál

DEF.PL.NOM house.PL.NOM come.PST.3PL again

so tópos it

LOC.DEF.SG.ACC place.SG.NOM 3.GEN

'The houses came to their place again.'

d. Ulaghátsh Cappadocian (Dawkins, 1916: 376)

na po jo épe

FUT go.PRS.1SG 1SG.NOM say.PST.3SG

ta do çerífos it

3PL.ACC DEF.SG.ACC man.SG.NOM 3.GEN

"I will go", she said to her husband.'

I propose that the unexpected occurrence of nominative-looking forms in accusative environments such as the definite direct object NP in (37a), the definite adpositional complement NPs in (37b) and (37c), and the definite indirect object NP in (37d) can be understood when examined in conjunction with a morphological innovation that affected the inflection of nouns in Cappadocian and which is generally referred to in the literature as agglutinative inflection (Horrocks, 2010: 403-404; Janse, 2001: 475-476, 2004: 9-12, 2009: 41, 2019; Johanson, 2002: 59-6o; Matras, 2009: 262-263, 2010: 75-76; Melissaropoulou, 2013: 321-327; Ralli, 2009: 99-102; Thomason and Kaufman, 1988: 219; Winford, 2003: 83, 2005: 405, 2010:181). 
In my recent analysis of the development of agglutinative inflection in Cappadocian (Karatsareas, 2011, 2016), I compare the variable inflection of nouns such as Sílata Cappadocian mílos 'mill' and Araván Cappadocian áropos 'man' with that of spit 'house' (38), (39). From a historical point of view, milos and áropos belong to IC1; spit belongs to IC6 (see Table 1). Unlike spit, whose inflection is stable and does not show variation, milos and áropos exhibit two inflectional paradigms: one inherited one that follows IC1 (38a), (39a) and one innovative one that follows IC6 (38b), (39b). On the basis of this evidence, I have argued that the Cappadocian innovation is best described in terms of a generalised inflectional class shift of nouns from their inherited ICs to IC6.

Sílata Cappadocian (Dawkins, 1916: 98)

SG NOM

a. IC1, inherited

b. IC1, innovative

c. IC6

$$
\text { mílo-s 'mill' }
$$
mílos- $\varnothing$ 'mill' spit- $\varnothing$ 'house'

$\begin{array}{clll}\text { ACC } & \text { mílo- } \varnothing & \text { mílos- } \varnothing & \text { spit- } \varnothing \\ \text { GEN } & - & \text { mílos-iu } & \text { spit-iú } \\ \text { PL NOM/ACC } & \text { míl-us }{ }^{11} & \text { mílos-ia } & \text { spít-ia }\end{array}$

(39) Araván Cappadocian (Dawkins, 1916: 104)

a. IC1, inherited b. IC1, innovative c. IC6

\begin{tabular}{clll} 
SG NOM & áropo-s 'man' & áropos- $\varnothing$ 'man' & spit- $\varnothing$ 'house' \\
\multicolumn{1}{c}{ ACC } & áropo- $(n a)^{12}$ & áropos- $\varnothing$ & spit- $\varnothing$ \\
GEN & aróp- $(u)$ & áropos-iu & spit-iú \\
PL NOM/ACC & aróp- $(i)$ & áropos-ia & spit-ia
\end{tabular}

Nouns of all ICs underwent the inflectional class shift. Examples include $\mathrm{IC}_{3}$ papás 'priest', IC4 néka 'woman', IC 5 k istro 'scraper', IC 7 púma 'cover'. In all cases, the shift involved the reanalysis of the inherited, often bimorphemic, nominative singular form as a monomorphemic base to which inflection subsequently applied by the suffixation of the zero suffix in the nominative/ accusative singular, $-i u$ in the genitive singular and $-i a$ in the nominative/

\footnotetext{
11 In Cappadocian, inanimate IC1 nouns form the nominative/accusative plural by means of the suffix -us.

12 In Araván, the accusative singular of IC1 nouns may be extended by the suffix -na (Dawkins, 1916: 104). See also Kim (2008).
} 
accusative plural (áropo-s 'NOM.sG' > áropos- : áropos- $\varnothing$ 'NOM/ACC.SG', áropos-iu 'GEN.SG', áropos-ia 'NOM/ACC.PL').

The shift, however, affected different types of nouns differently with respect to their ability to morphologically distinguish between the nominative and the accusative. As mentioned in Sections 3 and 4.1, nouns belonging to historically feminine and neuter ICs had already lost this ability before the shift was set in motion. In contrast, nouns that belonged to the historically masculine ICs $(1,2,3)$ moved from classes in which the two cases were expressed by two dis-

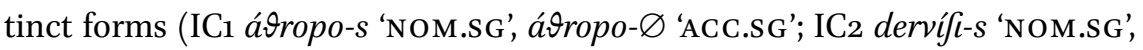
dervíf $(-\varnothing$ 'ACC.SG'; IC3 papá-s 'NOM.SG', papá- $\varnothing$ 'ACC.SG') to a class that uses only one syncretic form to express both, due to the fact that it is historically associated with the neuter gender. The impact this had on DCM can be illustrated by examples such as (40). In (40a), the head noun of the definite direct object NP is marked by the accusative, as expected. In this case, patifáxos retains its inherited IC1 inflection; cf. (38a), (39a). In (4ob), though, we find the historical nominative form, which evidences that the noun is undergoing shift to IC6 thus bleeding the application of the DCM pattern; cf. (38b), (39b).

(40) Araván Cappadocian (Fosteris, 1962: 162)

a. na

$\begin{array}{lll}\text { ítun } & \text { jusméf } & n a \\ \text { COP.PST.3SG } & \text { fate.sG.NOM } & \text { COMP } \\ \text { to } & \text { patifáxo } & \\ & & \end{array}$

take.PST.IPFV.1SG DEF.SG.ACC king.sG.ACC

'If only I got married to the king.'

b. as

MOD

pérnifka

c' eyó

to

take.PST.IPFV.1SG

and

1SG.NOM

DEF.SG.ACC king.sG.NOM

'If I got married to the king, too.'

Araván Cappadocian patifáxos retains the ability to formally realise the DCM pattern as its shift to IC6 is not yet complete. Phloïtá Cappadocian xorós 'dance', on the other hand, which also belonged historically to $\mathrm{IC} 1$, has completed the shift. As shown in (41), the same, historically nominative singular form is found in nominative contexts (41a) and in both definite and indefinite accusative contexts $(41 \mathrm{~b}, \mathrm{c})$ while the plural is formed by the suffixation of $-i a(41 \mathrm{~d})$, cf. 
spítia.xorós is now a full-fledged IC6 noun and can therefore no longer participate in DCM.

(41) Phloïtá Cappadocian
a. xorós me ta xuKéra
dance.SG.NOM COM DEF.PL.ACC spoon.PL.ACC
me téfça
сом tambourine.PL.ACC
'the dance with the spoons and the tambourines' (Tsitsopoulos, 1962: 49)
b. pçániskan éna xorós trayúðanan catch.PST.IPFV.3PL INDF dance.SG.ACC sing.PST.IPFV.3PL 'They would dance and sing.' (Kostakis, 1962: 15)

c. toplandú neklifás to xavlú

gather.PRS.3PL church.SG.GEN DEF.SG.ACC yard.sG.ACC

ce pçásne to xorós

and catch.PRS.PL DEF.SG.ACC dance.sG.ACC

'They gather at the church yard and dance.' (Tsitsopoulos, 1962: 50)

d. ta xorósia kolún tría

DEF.PL.NOM dance.PL.NOM last.PRS.3PL three

méres

day.PL.ACC

'The dancing lasts for three days.' (Tsitsopoulos, 1962: 50)

According to Dawkins (1916: 209), shifts to IC6 are most extensive in Araván, Ferték, Ghúrzono, Semenderé and Ulaghátsh Cappadocian. This accounts for the increased number of examples in which DCM does not appear to work as expected in these varieties compared to others in which shifts are limited and subject to semantic and phonological conditions (Karatsareas, 2011, 2016a). As a result, DCM has fallen almost completely into disuse as very few nouns preserve morphologically distinct forms for the nominative and accusative. This relation between DCM and noun inflection finds additional support in the fact that DCM in Pharasiot applies to all available nouns across the board and without exceptions, which cannot be unrelated to the fact that nouns in Pharasiot did not undergo any inflectional innovations identical, similar or even vaguely reminiscent of the Cappadocian shifts to IC6. 
In this article, I provided a synchronic analysis of Cappadocian and Pharasiot DCM as well as a diachronic account of its development in the two iAMGr dialects. My synchronic analysis showed that DCM is determined by definiteness, thus supporting Dawkins's (1916) and Janse's (2004) proposals and challenging Spyropoulos and Tiliopoulou's (2006) proposal, according to which DCM in iAMGr is determined by the referential property of specificity. The analysis also showed the formal implementation of Cappadocian and Pharasiot DCM to be improbable from a typological point of view. I argued this to be evidenced by the occurrence of the the suffix $-s$, an overt marker that alternates with zero in expressing the morphological distinction between nominative and accusative that DCM employs. In the two iAMGr dialects, $-s$ is found not on the head nouns of definite NPs - the marked class of objectsbut on those of indefinite NPs - the unmarked class of objects-, thus violating robust crosslinguistic tendencies previously identified by a number of scholars.

My diachronic analysis drew on these findings. Considering in combination the typological improbability of the Cappadocian and Pharasiot DCM pattern, the weak genetic link between the two dialects that excludes the possibility of its being an innovation shared by both on account of descent, and its similarity to Turkish DOM, I refined Dawkins's and Janse's earlier analyses on the origin of iAMGr DCM. I claimed that it developed as a result of contact with Turkish within a single linguistic micro-area in which all three languages were contiguously spoken. I argued that Cappadocian and Pharasiot adapted the originally non-differential case marking system of ModGr into a differential one by replicating the Turkish model by (a) matching the referential property of specificity with that of definiteness; and, (b) adopting the use of the nominative for the unmarked set of objects and the use of the accusative for the marked set of objects (non-specific $\Rightarrow$ zero-marked $\|$ indefinite $\Rightarrow$ nominative; specific $\Rightarrow$ accusative $\|$ definite $\Rightarrow$ accusative). I subsequently focused on a set of Cappadocian data in which the replicated DCM pattern is not adhered to. I proposed that the apparent violations are due to the fact that the morphological material used for the expression of DCM was affected by a morphological change whereby historical masculine nouns that preserved the ability to distinguish between the nominative and accusative shifted to a historical neuter IC that did not distinguish between the two cases. As a result, the morphological distinction upon which DCM was based was lost. DCM was therefore short-lived in Cappadocian but survived in Pharasiot, whose nouns did not undergo the IC shifts that Cappadocian nouns did. 


\section{Acknowledgments}

The research reported in this article is based on my 2011 doctoral dissertation, which I completed at the University of Cambridge under the supervision of Bert Vaux and with the financial support of the Greek State Scholarships Foun-

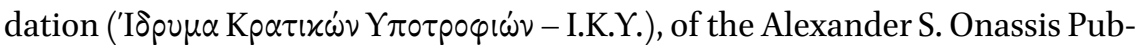
lic Benefit Foundation and of the George and Marie Vergottis Fund of the Cambridge European Trust. I thank the four anonymous reviewers of the article as well as the organisers the Differential Object Marking and Language Contact workshop, Anton Antonov and Alexandru Mardale, and the workshop audience for the most constructive and helpful comments on earlier versions of this work. All remaining errors are my own.

\section{References}

Aikhenvald, Alexandra Y. 2007. Grammars in contact: a cross-linguistic perspective. In Alexandra Y. Aikhenvald and Robert M.W. Dixon (eds.), Grammars in Contact: A Cross-Linguistic Typology, 1-66. Oxford: Oxford University Press.

Aikhenvald, Alexandra Y. and Robert M.W. Dixon. 2001. Introduction. In Alexandra Y. Aikhenvald and Robert M.W. Dixon (eds.), Areal Diffusion and Genetic Inheritance: Problems in Comparative Linguistics, 1-26. Oxford: Oxford University Press.

Aissen, Judith. 2003. Differential object marking: iconicity vs. economy. Natural Language and Linguistic Theory 21(3): 435-483.

Alexiadou, Artemis and Jaklin Kornfilt. 2010. Object positions and the role of clitics in Cappadocian. Paper presented at the Mediterranean Syntax Meeting 3, 8-10 October 2010, National and Kapodistrian University of Athens, Greece.

Anastasiadis, Vasileios K. 1976. I syntaxi sto farasiotiko idioma tis Kappadokias se sygkrisi pros ta ypoloipa idiomata tis Mikras Asias, kathos kai pros tin archaia, ti mesaioniki kai ti nea elliniki glossa [The syntax of the Pharasiot dialect of Cappadocia in comparison with the rest of the Asia Minor dialects as well as with the Ancient, Medieval and Modern Greek language]. Thessaloniki.

Andriotis, Nikolaos P. 1948. To glossiko idioma ton Farason (Le dialecte de Farassa). Athens: Ikaros.

Aydemir, Yasemin. 2004. Are Turkish preverbal bare nouns syntactic arguments? Linguistic Inquiry 35(3): 465-474.

Bağraçık, Metin. 2013. Marked yes/no questions in Cappadocian. In Mark Janse, Brian Joseph, Angela Ralli and Metin Bağraç̧ı (eds.), Proceedings of the $5^{\text {th }}$ International Conference on Modern Greek Dialects and Linguistic Theory, September 20-22, 2012, Ghent, Belgium, 19-34. Patras. 
Bağnaçık, Metin. 2018. Pharasiot Greek: Word Order and Clause Structure. PhD dissertation, University of Ghent.

Barristella, Edwin. 1990. Markedness: The Evaluative Superstructure of Language. Albany, N.Y.: State University of New York Press.

Bossong, Georg. 1982. Der präpositionale Akkusativ im Sardischen. In Otto Winkelmann and Maria Braisch (eds.), Festschrift für Johannes Hubschmid zum 65. Geburtstag, 579-599. Bern: Francke.

Bossong, Georg. 1985. Empirische Universalienforschung: Differentielle Objektmarkierung in den neuiranischen Sprachen. Tübingen: Gunter Narr.

Bossong, Georg. 1991. Differential object marking in Romance and beyond. In Dieter Wanner and Douglas A. Kibbee (eds.), New Analyses in Romance Linguistics: Selected Papers from the XVIII Linguistic Symposium on Romance Languages, Urbana-Champaign, April 7-9, 1998, 143-170. Amsterdam/Philadelphia: John Benjamins.

Bossong, Georg. 1998. Le marquage differentiel de l'objet dans les langues d'Europe. In Jack Feuillet (ed.), Actance et valence dans les langues de l'Europe, 193-258. Berlin/ New York: Mouton de Gruyter.

Campbell, Lyle. 2006. Areal linguistics: a closer scrutiny. In Yaron Matras, April McMahon and Nigel Vincent (eds.), Linguistic Areas: Convergence in Historical and Typological Perspective, 1-31. Basingstoke: Palgrave Macmillan.

Chiriacescu, Sofiana and Klaus von Heusinger. 2010. Discourse prominence and pemarking in Romanian. International Review of Pragmatics 2(2): 298-332.

Clairis, Christos and Georgios Babiniotis. 2004. Grammatiki tis Neas Ellinikis: Domoleitourgiki - epikoinoniaki. I2: Ta onomatika stoicheia (arthra, epitheta, antonymies): $i$ exeidikefsi tis anaforas [Modern Greek Grammar: Structural - functional - communicative. I2: Nominal elements (articles, adjectives, pronouns): specifying reference]. Athens: Ellinika Grammata.

Comrie, Bernard. 1979. Definite and animate direct objects: a natural class. Linguistica Silesiana 3: 13-21.

Comrie, Bernard. 1989. Language Universals and Linguistic Typology: Syntax and Morphology. Chicago: The University of Chicago Press.

Corbett, Greville G. 1991. Gender. Cambridge: Cambridge University Press.

Croft, William. 1988. Agreement vs. case marking and direct objects. In Michael Barlow and Charles A. Ferguson (eds.), Agreement in Natural Language: Approaches. Theories. Descriptions, 159-179. Stanford, CA: CsLi Publications.

Croft, William. 2003. Typology and Universals. Cambridge: Cambridge University Press.

Dahl, Östen. 2000. Animacy and the notion of semantic gender. In Barbara Unterbeck, and Matti Rissanen, Terttu Nevalainen and Mirja Saari (eds.), Gender in Grammar and Cognition. I: Approaches to Gender. II: Manifestations of Gender, 99-115. Berlin/ New York: Mouton de Gruyter. 
Danon, Gabi. 2001. Syntactic definiteness in the grammar of Modern Hebrew. Linguistics 39(6): 1071-1116.

Dalrymple, Mary and Irina Nikolaeva. 2011. Objects and Information Structure. Cambridge: Cambridge University Press.

Dawkins, Richard M. 1916. Modern Greek in Asia Minor: A Study of the Dialects of Silli, Cappadocia and Phárasa with Grammar, Texts, Translations and Glossary. Cambridge: Cambridge University Press.

Dawkins, Richard M. 1950. Review of N.P. Andriotis's To glossiko idioma ton Farason. Byzantion 20: 354-364.

Drettas, George. 1997. Aspects pontiques. Paris: Association de recherches pluridisciplinaires.

Drettas, George. 1999. Ergative versus accusative structure: the case of Pontic Greek in a typological perspective. Mediterranean Language Review 11: 90-117.

Erdal, Marcel. 2004. A Grammar of Old Turkic. Leiden. Brill.

Erguvanl, Eser E. 1984. The Function of Word Order in Turkish Grammar. Berkeley: University of California Press.

Fosteris, Dimitrios. 1952. To Aravanion [Araván]. Mikrasiatika Chronika 5: 133-177.

Fosteris, Dimitrios and Ioannis I. Kesisoglou. 196o. Leksilogio tou Aravani (Vocabulaire d'Aravani). Athens: Institut Français d'Athènes.

Givón, Talmy. 1978. Definiteness and referentiality. In Joseph H. Greenberg, Charles A. Ferguson and Edith A. Moravcsik (eds.), Universals of Human Language IV: Syntax, 291-330. Stanford: Stanford University Press.

Glinert, Lewis. 1989. The Grammar of Modern Hebrew. Cambridge: Cambridge University Press.

Göksel, Aslı and Celia Kerslake. 2005. Turkish: A Comprehensive Grammar. London/ New York: Routledge.

Guardiano, Cristina. 2010. L' oggetto diretto preposizionale in siciliano: una breve rassegna e qualche domanda. In Jacopo Garzonio (ed.), Quaderni di lavoro ASIt 11 (2010): Studi sui dialetti della Sicilia, 95-115. Padova: Unipress.

Hatzidakis, Georgios N. 1934 [1911/1912]. Peri tis pontikis dialektou kai idia peri ton en afti analogikon schimatismon [On the Pontic dialect and especially on the analogical formations found in it]. In Glossologikai Erevnai 1 [Linguistic Studies 1], 265-291. Athens: Academy of Athens.

Heine, Bernd and Tania Kuteva. 2005. Language Contact and Grammatical Change. Cambridge: Cambridge University Press.

von Heusinger, Klaus. 2002. Specificity and definiteness in sentence and discourse structure. Journal of Semantics 19(3): 245-274.

von Heusinger, Klaus. 2008. Verbal semantics and the diachronic development of DOM in Spanish. Probus 2o(1): 1-31. 
von Heusinger, Klaus. 2011a. Specificity. In Klaus von Heusinger, Claudia Maienborn and Paul Portner (eds.), Semantics: An International Handbook of Natural Language Meaning. Volume 2, 1025-1058. Berlin/Boston: De Gruyter Mouton.

von Heusinger, Klaus. 2011b. Specificity, referentiality and discourse prominence: German indefinite demonstratives. In Ingo Reich, Eva Horch and Dennis Pauly (eds.), Sinn und Bedeutung 15: Proceedings of the 2010 Annual Conference of the Gesellschaft für Semantik, 9-30. Saarbrücken: Saarland University Press.

von Heusinger, Klaus and Jaklin Kornfilt. 2005. The case of the direct object in Turkish: semantics, syntax and morphology. Turkish Languages 9: 3-44.

Holton, David, Peter Mackridge, and Irene Philippaki-Warburton. 1997. Greek: A Comprehensive Grammar of the Modern Language. London/New York: Routledge.

Horrocks, Geoffrey. 2010. Greek: A History of the Language and Its Speakers. Malden, MA/Oxford: Wiley-Blackwell.

Iemmolo, Giorgio. 2011. Towards a Typological Study of Differential Object Marking and Differential Object Indexing. PhD dissertation, Università degli studi di Pavia.

Iemmolo, Giorgio. 2013. Symmetric and asymmetric alternations in direct object encoding. STUF - Language Typology and Universals 66(4): 378-403.

Igartua, Iván. 2005. Origen y evolución de la flexión nominal eslava. Bilbao: Universidad del País Vasco/Euskal Herriko Unibertsitatea.

Janse, Mark. 2001. Morphological borrowing in Asia Minor Greek. In Yoryia Aggouraki, Amalia Arvaniti, Jim Davy, Dionysis Goutsos, Marilena Karyolaimou, Anna Panagiotou, Andreas Papapavlou, Pavlos Pavlou and Anna Roussou (eds.), Proceedings of the $4^{\text {th }}$ International Conference on Greek Linguistics, Nicosia 17-19 September 1999, 473-479. Thessaloniki: University Studio Press.

Janse, Mark. 2002. Aspects of bilingualism in the history of the Greek language. In James Noel Adams, Mark Janse and Simon Swain (eds.), Bilingualism in Ancient Society: Language Contact and the Written Text, 332-390. Oxford: Oxford University Press.

Janse, Mark. 2004. Animacy, definiteness, and case in Cappadocian and other Asia Minor Greek dialects. Journal of Greek Linguistics 5: 3-26.

Janse, Mark. 2009. Greek-Turkish language contact in Asia Minor. Études Helléniques/ Hellenic Studies 17(1): 37-54.

Janse, Mark. 2019. Agglutinative Noun Inflection in Cappadocian. In Angela Ralli (ed.), The Morphology of Asia Minor Greek: Selected Topics, 66-115. Leiden/Boston: Brill.

Johanson, Lars. 1999. Contact-induced change in a code-copying framework. Contributions to the Sociology of Language 86: 285-314.

Johanson, Lars. 2002. Structural Factors in Turkic Language Contacts. Richmond: Curzon.

Karatsareas, Petros. 2009. The loss of grammatical gender in Cappadocian Greek. Transactions of the Philological Society 107(2): 196-230. 
Karatsareas, Petros. 2011. A Study of Cappadocian Greek Nominal Morphology from a Diachronic and Dialectological Perspective. $\mathrm{PhD}$ dissertation, University of Cambridge.

Karatsareas, Petros. 2013. Understanding diachronic change in Cappadocian Greek: the dialectological perspective. Journal of Historical Linguistics 3(2): 192-229.

Karatsareas, Petros. 2014. On the diachrony of gender in Asia Minor Greek: the development of semantic agreement in Pontic. Language Sciences 43: 77-101.

Karatsareas, Petros. 2016a. Convergence in word structure: revisiting 'agglutinative' noun inflection in Cappadocian Greek. Diachronica 33(1): 31-66.

Karatsareas, Petros. 2016b. The adpositional cycle in Asia Minor Greek: a tale of multiple causation. Journal of Greek Linguistics 16(1): 47-86.

Karatsareas, Petros and Thanasis Georgakopoulos. 2016. From syntagmatic to paradigmatic spatial zeroes: the loss of the preposition se in inner Asia Minor Greek. sTUF Language Typology and Universals 69(2): 309-340.

Keenan, Edward. 1976. Towards a universal definition of "subject". In Charles N. Li (ed.), Subject and Topic, 303-333. New York: Academic Press.

Kesisoglou, Ioannis I. 1951. To glossiko idioma tou Oulagats (Le dialecte d'Oulagatch). Athens: Institut Français d'Athènes.

Kim, Ronald. 2008. An individual twist on the individualizing suffix: definite $n$-stem nouns in Pontic Greek. Glotta 84(1/4): 72-113.

Klein, Udo and Peter de Swart. 2011. Case and referential properties. Lingua 121(1): 3-19.

Klenin, Emily R. 1983. Animacy in Russian: A New Interpretation. Columbus: Slavica.

Kornfilt, Jaklin. 1984. Case Marking, Agreement, and Empty Categories in Turkish. PhD dissertation, Harvard University.

Kornfilt, Jaklin. 1997. Turkish. London: Routledge.

Kornfilt, Jaklin. 2009. DOM and two types of DSM in Turkish. In Helen de Hoop and Peter de Swart (eds.), Differential Subject Marking, 79-111. Dordrecht: Springer.

Kostakis, Athanasios P. 1959. Glossikon ylikon ek katoikon tou choriou Misthi Kappadokias egkatestimenon nyn eis Agioneri Axioupoleos Makedonias [Linguistic material from inhabitants of the Cappadocian village of Misthi now living in Agioneri of Macedonian Axioupolis]. Manuscript No. Research Centre for Modern Greek Dialects, Academy of Athens.

Kostakis, Athanasios P. 1962. Glossikon ylikon apo ta Flogita Chalkidikis (prosfygikon chorion) [Linguistic material from the village of Flogita in Chalkidiki (refugee village)]. No. Research Centre for Modern Greek Dialects, Academy of Athens.

Kostakis, Athanasios P. 1968. To glossiko idioma tis Sillis [The dialect of Silli]. Athens: Centre for Asia Minor Studies.

Koutita-Kaimaki, Myrto. 1977/1978. I onomastiki se -n ton arsenikon onomaton tis Pontiakis [The nominative in -n of the masculine nouns of Pontic]. Archeion Pontou 34: $259-298$. 
Lekakou, Marika and Petros Karatsareas. 2016. Marking definiteness multiply: evidence from two varieties of Greek. Studies in Greek Linguistics 36: 189-204.

Lyons, Christopher. 1999. Definiteness. Cambridge: Cambridge University Press.

Malchukov, Andrej L. 2008. Animacy and asymmetries in differential case marking. Lingua 118(2): 203-221.

Manolessou, Io and Stamatis Beis. 2006. Syntactic isoglosses in Modern Greek dialects: the case of the indirect object. In Mark Janse, Brian Joseph and Angela Ralli (eds.), Proceedings of the 2nd International Conference on Modern Greek Dialects and Linguistic Theory, Mytilene, Greece, 30 September - 3 October 2004, 220-235. Patras: University of Patras.

Manolessou, Io. 2019. The historical background of the Asia Minor dialects. In Angela Ralli (ed.), The Morphology of Asia Minor Greek: Selected Topics, 20-65. Leiden/ Boston: Brill.

Matras, Yaron. 2009. Language Contact. Cambridge: Cambridge University Press.

Matras, Yaron. 2010. Contact, convergence, and typology. In Raymond Hickey (ed.), The Handbook of Language Contact, 66-85. Malden, MA/Oxford: Wiley-Blackwell.

Matras, Yaron and Jeanette Sakel. 2007. Investigating the mechanisms of pattern replication in language convergence. Studies in Language 31(4): 829-865.

Mavrochalyvidis, Georgios and Ioannis I. Kesisoglou. 1960. To glossiko idioma tis Axou (Le dialecte d'Axos). Athens: Institut Français d'Athènes.

Melis, Chantal and Marcela Flores. 2009. On the interplay between forces of erosion and forces of repair in language change. Folia Linguistica Historica 30: 271-310.

Melissaropoulou, Dimitra. 2013. Reorganization of grammar in the light of the language contact factor: a case study on Grico and Cappadocian. In Mark Janse, Brian Joseph, Angela Ralli and Metin Bağrnaçlk (eds.), Proceedings of the $5^{\text {th }}$ International Conference on Modern Greek Dialects and Linguistic Theory, September 20-22, 2012, Ghent, Belgium, 311-334. Patras.

Moravcsik, Edith. A. 1978. On the case marking of objects. In Joseph H. Greenberg, Charles A. Ferguson, and Edith A. Moravcsik (eds.), Universals of Human Language IV: Syntax, 249-289. Stanford: Stanford University Press.

Napoli, Maria. 2009. Aspects of definiteness in Greek. Studies in Language 33(3): 569-611.

Oikonomidis, Dimosthenis I. 1958. Grammatiki tis ellinikis dialektou tou Pontou. Leksikografikon Deltion, Parartima 1 [Grammar of the Greek dialect of Pontus. Lexicographic Bulletin, Supplement 1]. Athens: Academy of Athens.

Papadopoulos, Anthimos A. 1955. Istoriki grammatiki tis Pontikis dialektou [Historic grammar of the Pontic dialect]. Athens: Epitropi Pontiakon Meleton.

Ralli, Angela. 200o. A feature-based analysis of Greek nominal inflection. Glossologia 11/12: 201-227.

Ralli, Angela. 2005. Morfologia [Morphology]. Athens: Patakis. 
Ralli, Angela. 2009. Morphology meets dialectology: insights from Modern Greek dialects. Morphology 19(1): 87-105.

Revithiadou, Anthi and Vassilios Spyropoulos. 2009. Ofitiki Pontiaki: erevna glossikis katagrafis me emfasi sti diachronia kai synchronia tis dialektou [Ophis Pontic: a study of linguistic documentation with an emphasis on the diachrony and synchrony of the dialect]. Available online at http://www.latsis-foundation.org/content/ actions/action_343/inline/ell/actionInline_343_5553519e48b78.pdf. Accessed on 7 July 2016.

Schroeder, Christoph. 2006. Articles and article systems in some areas of Europe. In Giuliano Bernini and Marcia L. Schwartz (eds.), Pragmatic Organization of Discourse in the Languages of Europe, 545-611. Berlin/New York: Mouton de Gruyter.

Seržant, Ilja A. and Alena Witzlack-Makarevich. 2018. Differential argument marking: patterns of variation. In Ilja Seržant, Alena A. Witzlack-Makarevich, and Kelsey Mann (eds.), Diachrony of Differential Argument Marking, 1-40. Berlin: Language Science Press.

Spyropoulos, Vassilios. 2016. Diaforopoiitiki dilosi orismatos sti mikrasiatiki elliniki [Differencial argument marking in Asia Minor Greek]. Studies in Greek Linguistics 36: $395^{-408 .}$

Spyropoulos, Vassilios and Konstantinos Kakarikos. 2009. Aspects of dialectal variation in the Greek declension: a feature-based approach. In Geert Booij, Angela Ralli, and Sergio Scalise (eds.), Morphology and Dialectology: On-line Proceedings of the $6^{\text {th }}$ Mediterranean Morphology Meeting (MM6), 49-62. Patras: University of Patras.

Spyropoulos, Vassilios and Konstantinos Kakarikos. 2011. A feature-based analysis of Cappadocian Greek nominal inflection. In Mark Janse, Brian Joseph, Pavlos Pavlou, Angela Ralli, and Spyros Armosti (eds.), Studies in Modern Greek Dialects and Linguistic Theory, 203-213. Nicosia: Research Centre of Kykkos Monastery.

Spyropoulos, Vassilios and Maria-Anna Tiliopoulou. 2006. Definiteness and case in Cappadocian Greek. In Mark Janse, Brian Joseph, and Angela Ralli (eds.), Proceedings of the $2^{\text {nd }}$ International Conference on Modern Greek Dialects and Linguistic Theory, Mytilene, Greece, 30 September - 3 October 2004, 365-378. Patras: University of Patras.

Stolz, Thomas. 2006. All or nothing. In Yaron Matras, April McMahon, and Nigel Vincent (eds.), Linguistic Areas: Convergence in Historical and Typological Perspective, 32-50. Basingstoke: Palgrave Macmillan.

Stolz, Thomas, Sander Lestrade, and Christel Stolz. 2014. The Crosslinguistics of ZeroMarking of Spatial Relations. Berlin/Boston: De Gruyter.

de Swart, Peter. 2007. Cross-linguistic Variation in Object Marking. Nijmegen: LOT Publications.

Tekin, Talât. 1968. A Grammar of Orkhon Turkic. The Hague: Mouton. 
Theofanopoulou-Kontou, Dimitra, Georgia Katsimali, Amalia Moser, Kiki Nikiforidou, and Despina Chila-Markopoulou. 1998. Themata neoellinikis syntaxis 2: TheoriaAskiseis [Topics in Greek syntax 2: Theory - exercises]. Athens: National and Kapodistrian University of Athens.

Thomason, Sarah G. and Terrence Kaufman. 1988. Language Contact, Creolization, and Genetic Linguistics. Berkeley: University of California Press.

Tompaidis, Dimitrios. 1980. Symboli stin erevna tou onomatikou synolou tis Pontiakis [Contribution to the study of the Pontic nominal group]. Archeion Pontou 36: 220-237.

Tompaidis, Dimitrios. 1988. I Pontiaki dialektos: dialektika charaktiristika, katataksi idiomaton, dialektika keimena. Archeion Pontou, Parartima 17 [The Pontic dialect: dialectal characteristics, dialectal classification, dialectal texts. Pontus Archive, Supplement 17]. Athens: Epitropi Pontiakon Meleton.

Tsitsopoulos, Eleftherios. 1962. Syllogi glossikou kai laografikou ylikou ek tou choriou Flogita Chalkidikis (prosfygon tou omonymou choriou Kappadokias) [Collection of linguistic and folkoric material from the village of Flogita in Chalkidiki (from refugees of the homonymous village in Cappadocia)]. Manuscript No 811. Research Centre for Modern Greek Dialects, Academy of Athens.

Tzartzanos, Achilleas A. 1989. Neoelliniki syntaxis (tis koinis dimotikis): Tomos A' [Modern Greek syntax (of the common demotic): Volume A]. Thessaloniki: Kyriakidi.

Tzitzilis, Christos. 1989. Zu den griechisch-türkischen Sprachbeziehungen. Linguistique Balkanique 32(3/4): 185-197.

Winford, Donald. 2003. An Introduction to Contact Linguistics. Oxford: Blackwell.

Winford, Donald. 2005. Contact-induced changes: classification and processes. Diachronica 22(2): 373-427.

Winford, Donald. 2010. Contact and borrowing: In Raymond Hickey (ed.), The Handbook of Language Contact, 170-187. Malden, MA/Oxford: Wiley-Blackwell. 